\title{
Post-Brexit. The Politics of Resentment and EU Reintegration: Creating A New Legal Constitution for Capitalism
}

\author{
K.A.C. O’Rourke \\ Washington College of Law, American University, Washington, DC \\ GeoNOMOS777@gmail.com
}

O'ROURKE, K.A.C. Post-Brexit. The Politics of Resentment and EU Reintegration: Creating A New Legal Constitution for Capitalism. International and Comparative Law Review, 2019, vol. 19, no. 1, pp. 38-73. DOI: 10.2478/iclr-2019-0002

\begin{abstract}
Summary: The GeoNOMOS model introduced in Part I, is a qualitative descriptive taxonomy updating traditional notions of sovereignty for this century and was generally applied to the 2016-2018 BREXIT divorce negotiations between the U.K. and the remaining 27EU suggesting a reintegration and redefinition of the legitimate expression of sovereignty in the region.[Diagram 01] The taxonomy depicts a framework of liberty that functions simultaneously within the core function of the State at the intersection of a vertical axis depicting a State's domestic operation and a horizontal axis depicting the State function as part of an international community of States. The GeoNOMOS confirms two primary roles for the $21^{\text {st }}$ century sovereign State: [1] to protect participatory democracy based on individual liberty. This is generally accomplished by the State supporting broad diversity and its cultural heritage as well as fully funded, functional and integrated domestic institutions along its vertical axis, and [2] to promote an enterprise of law supporting a global society of economic traders along its horizontal axis. This primary role of the State occurs at its core when all three essential capital resources -economic capital, social capital, and human capital - remain highly integrated and in balance. Part II specifically highlights economic capital development and utilization at the core function of the State - a shifting dynamic that has influenced most all of the BREXIT 2017-2019 negotiations to date. The December 2018 EU - BREXIT
\end{abstract}

\footnotetext{
Dr. K.A.C. O'Rourke, JD, M.Div., LL.M; holds a Doctorate of Juridical Science with dual Masters of Law [LL.M; International Law and Business ; Government Law \& Regulation] from Washington College of Law/ American University, Washington, DC./USA; See "The Crossroads of Globalization, Human Rights and Rule of Law: Creating a Legal Culture for Human Rights and Designing a GeoNOMOS Model for the State"/2012 [SJD Dissertation][Washington College of Law/American University]; O'Rourke has taught as adjunct faculty at Washington College of Law and holds a Juris Doctorate from Drake University Law School; O'Rourke is a private consultant, educator and serves in the core executive leadership circle at The Bridging Institute in Maryland USA; ORourke has published in the area of State sovereignty, globalization and economics, participatory democracy and individual liberty. The GeoNOMOS๑ model is a copyrighted series of schematics designed by ORourke, depicting 21st century transitions in the role of the nation State and its legitimate expression of sovereignty. Interdisciplinary comments are welcomed and encouraged at GeoNOMOS777@gmail.com.
} 
Withdrawal Agreement a Declaration repeatedly failed U.K. parliamentary adoption between January - June 2019 forcing Theresa May's resignation as Prime Minister. The most contentious quagmire of the BREXIT Withdrawal Agreement was in the structuring of rules of law around regulating economic capital, financial markets, and global marketplace function for any future UK - EU partnership. The political chaos around BREXIT was feared by the EU political elite in terms of its disruptive impact on the May 2019 European Parliament elections and future EU budget planning and priorities. But the 2019 EU Parliament election was already a process divided on questions of political party legitimacy since 2014 with a deepening of the "politic of resentment" on the Continent between 2016-2018. The EUP elections of May 2019 have caused the biggest political shift in the EU for forty years. Part II engages this "politic of resentment" best described as a steady rise of populism across the region and Continent that challenges the post-World War II notions of liberal democracy, the values of EU solidarity, and the traditional role of the "welfare state." More to the point, the U.K. electorate was not the only EU member outlining an action plan based on its politic of resentment in the 2016-2018 national election cycles - electoral politics in Greece, Italy, Poland, Hungary, Austria, Germany, France, Czech Republic, and Spain aggressively promoted rights of sovereign States. These national elections and the 2019 EUP elections attacked fragmented EU economic policy and highlighted the democratic imbalances of EU institutions in their day-to-day operations. These calls for an institutional "course correction" within the EU are shattering fifty years of solidarity and crying out for a redefinition of democracy and new rules of law for economic models relevant to the $21^{\text {st }}$ century. Economic, legal, and historical research by Piketty, Rodrik, Grewal, and others who support democracy, point to documented gaps in economic capital at the level of the State, in global capital formation and in growing wealth inequality, all alarming trends which are part of the "politic of resentment". Their research calls for creating a new $21^{\text {st }}$ century legal constitution for capitalism as a course correction for the first legal constitution for capitalism, eg, colonialism. Picketty and Grewal argue new approaches are needed to replace both the post-war "welfare State" [1945-1979] and now, the capitalist ideology of neoliberalism [c.1980-2010], decried as defunct even by the International Monetary Fund. Part II suggests a legal reconfiguration for economic capital development and utilization -one operating inside the GeoNOMOS framework of liberty, first to support its four cornerstones and its enterprise of law and, then, based on those choice sets, to design a new paradigm for capitalist globalization in the marketplace. ${ }^{1}$

Keywords: Sovereignty; BREXIT; GeoNOMOS Model; Economic Globalization; Piketty; Politics of Resentment; European Union; Framework of Liberty; Legal Constitution for Capitalism

\section{Introduction}

As BREXIT continues to demonstrate widespread U.K. political contestation, it became more obvious as 2019 deadlines for ratification passed, that there were no easy legislative answers in London or in Brussels. BREXIT was stuck indefi-

1 O'ROURKE, K.A.C. Sovereignty Post-Brexit, The State's Core Function and EU Reintegration. European Studies: The Review of European Law, Economics and Politics, 2017, vol. 4, pp.140-164. 
nitely in a political gridlock. The chaos became especially evident as debate and adoption of the formal BREXIT Withdrawal Agreement and its informal Political Declaration reflect how deeply interwoven trade, taxes, tariffs, geographic borders, and integrated economic capital transactions hindered the U.K. as it wrestled with the 2016 populist demand to "reclaim" British sovereignty by divorcing the European Union. ${ }^{2}$ As discussed in Part I, the 2016 BREXIT vote highlighted deep fissures in U.K.'s democratic 'social contract' as voters blamed longstanding austerity measures for weakening domestic investments in health, jobs, education and housing. Voters demanded EU money contributions be retrieved, and redirected to U.K. domestic priorities. The 2017-2018 negotiations and the 2019 failed ratification of BREXIT agreement continued to reflect deep political and cultural divides coupled with the 2016 BREXIT vote where U.K. citizens gave political leaders absolutely no direction on specific policies or programs to be included in the European Union divorce settlement process now scheduled for October 2019. An unlikely alliance of BREXIT supporters for EU departure and those who always sought to remain inside the EU came together as strange political bedfellows to defeat Theresa May's proposed last attempt on the BREXIT agreement in May 2019 and force her resignation as Prime Minister. ${ }^{3}$

Most offensive in the legally-binding EU-BREXIT Withdrawal Agreement was a "transition or implementation period" to run between 2019-2021 dur-

2 The Withdrawal Agreement: Commission to the EU27, 14 November 2018,TF50[2018] Draft Agreement on the Withdrawal of the United Kingdom of Great Britain and Northern Ireland from the EU and the European Atomic Energy Community as agreed on 14 November 2018 in eu.europan.eu. [Note: The Political Declaration set out the framework for the future relations between European Union and the United Kingdom is also subject to U.K. Parliamentary ratification and accompanies The Withdrawal Agreement, specifically endorses future relations including instructions to negotiators who will deliver the final terms covering the parties' economic relationships at the end of 2020] ; see also High Court of Justice, 3rd November 2016, R[Miller] v The Secretary of State for Exiting the European Union, concluding that Article 50 TEU must always be read in conjunction with Article 4 TUE requiring full member cooperation] [Note also that while many of the U.K. 2019 Parliamentary discussions of the BREXIT process may have reflected the procedures around triggering of Article 50 TEU in March 2017 ; many MPs in the U.K. Parliament considered unilateral termination and withdrawal as a process without consideration of other Article $4, \mathrm{TEU}$ regulations and procedures as underlying treaty legal commitments and the rule of law.]

3 SANFORD, Alasdair. Both Brexit and Remain MPs Opposed May's Deal and Why [online]. Available at: <https://www.euronews.com/2018/12/07/what-is-in-theresa-may-s-brexitdeal-and-why-is-it-so-unpopular> [Accessed 25 May 2019] [Noting that The long Withdrawal Agreement (on the terms of the UK's exit) and shorter Political Declaration (on the future relationship) were the result of 18 months of negotiations. The deal has been approved by leaders of the other $27 \mathrm{EU}$ countries, promoted by Brussels as the only deal available. Parliamentary approval in the UK is needed for the divorce agreement to be implemented. Following the defeat in U.K. Parliament, the path ahead is shrouded in uncertainty reflecting the very chaos Theresa May was trying to avoid. But as things stand, by law the UK is set to leave the EU in October 2019 - deal or no deal.] 
ing which many existing UK-EU economic, trade, remuneration and policy arrangements would actually stay in place. Although no longer an EU member, the UK would still be required to conform to EU rules during this period.. The 26-page Political Declaration accompanied the Withdrawal Agreement and set out the basis for future relations, including economic globalization and trade. This Declaration is not legally binding but defends the core principles outlined by each party; namely, [a] the integrity of the single market and customs union for the EU, and [b] the sovereignty for the UK. The accord also settled a variety of issues untangling the UK's 45-year membership in the EU, largely confirming terms agreed earlier in the 2017-2018 negotiations on two areas: money [all matters related primarily to economic capital] and citizens' rights. The accord established a mechanism for calculating the financial settlement that the UK owes the EU to meet its obligations with estimates set to be above $€ 40$ billion. It also includes contributions to be paid during the planned transition period to end in December 2020. If the transition period is ultimately extended for a second time, of course, more EU payments by the U.K. would be due. ${ }^{4}$

In the wake of the 2019 continuing British parliamentary defeat of the 2018 UK-EU BREXIT deal, preparations and public debate intensified for the possibility of a BREXIT "no deal" - where the United Kingdom would leave the European Union without an agreement. Implications for a BREXIT "no deal" were vehemently outlined by numerous groups - The World Trade Organization predicted a lowering in the rank of the U.K. as a trading partner. Economists and corporations pointed to a 2019 global recession. The International Monetary Fund argued the long term negative impact on Europe as a Continent would be significantly hurt. ${ }^{5}$ Many citizens' rights groups complained about being used as an "economic bargaining chip". 6

4 Ibid, [pointing out that many Brexiteers hate the financial settlement because it still involves large sums being paid to Brussels and brings no guarantees regarding the future relationship. However, the EU made it clear from the outset that financial arrangements were about settling the bill for prior U.K. commitments undertaken and that to renege on these commitments would seriously damage the UK's international reputation] [AUTHOR NOTE: these types of contingency matters are not noted in Article 50 of the EU Treaty which permits a State partner to withdraw but rather, becomes a political and negotiating procedural matters of great consequences; other EU member States who may contemplate their own exit will calculate terms and condition of Article 50 based on BREXIT]

5 BREXIT Global Recession. [Online] Available at <https://www.independent.co.uk/voices/ brexit-global-recession-germany-stock-markets-crash-record-closing-highs-a 8793401. html> [Accessed 25 May 2019][noting that the UK accounts for about 13\% of the EU's trade in goods and services, according to the International Monetary Fund. The IMF has warned that economic growth across the remaining $27 \mathrm{EU}$ states would fall by up to 1.5 percent in the long run and employment would fall by 0.7 percent, if the UK fell back on WTO rules to trade with the bloc after Brexit ; discussions about a 2019 global recession continue]

6 No Deal Brexit Like Jumping Off Cliff Without Parachute Says Former WTO Leader. 
The consequences of a "no-deal Brexit" particularly on economic capital as related to trade remain the subject of fierce and increasingly acrimonious debate in the UK even into the May 2019 European Parliament elections. Opponents predicted cross-border disruption, higher prices and a shortage of essential goods. The European Commission continued to argue well into 2019 that a BREXIT "no-deal" would see a hard border on the island of Ireland. ProBREXIT economists argued that because most world trade is done on legal rules and trade terms determined by the World Trade Organization [WTO], the UK would still have access to EU markets. However, many other economists and academics argued that although the UK could indeed adjust, by falling under WTO terms, these arrangements would be damaging for several sectors of the British economy including services, manufacturing and agriculture. ${ }^{7}$

[Online] Available at: <https://www.euronews.com/2019/02/22/no-deal-brexit-like-jumping-off-cliff-without-parachute-says-former-wto-leader $>$ February 22, 2019. [Accessed 25 May 2019] [Former WTO Director General suggested that final push in the U.K. risks moving the country into lower rank trade partnerships, capital markets and treaty agreement including border controls; concluding that the U.K. will not be able to recover its desired dominance through bilateral trade agreements when the entire world is moving toward market integrations and new forms of globalization in regulatory zones that cover over 500 million people]; See also: What Would A No Deal Brexit Mean for Citizen Rights. [online] Available at: <https://www.euronews.com/2019/01/10/what-would-a-no-dealbrexit-mean-for-citizens-rights $>$ February 22,2019. [Accessed 25 May 2019][offering a nicely detailed legal summary by country of the BREXIT impact on citizen rights across the EU and the Continent as a whole]; see also BLOCK, Pauline. Amendment to May's BREXIT Could Protect UK and EU Citizen Rights. [online] Available at:<https://www. euronews.com/2019/02/21/amendment-to-may-s-brexit-deal-could-protect-uk-and-eucitizens-rights> February 22,2019. [Accessed 20 May 2019][British citizens in the EU and EU citizens in the UK could lose their rights overnight: they are only guaranteed if the May's Withdrawal Agreement is adopted by MPs; Rights groups which fights for the rights of EU citizens in the UK and British people in Europe, have called to protect citizens rights in case of a "no deal Brexit" for months; In a BREXIT "no deal" situation, without such an amendment protecting their rights, citizens in both the UK and the EU would fall under the immigration policy of their country of residence] AUTHORS NOTE: the irony of this predicament is that immigration policy and EU mandates around immigration was a foundational issue in the original 2016 BREXIT vote.

7 SANFORD, Alasdair. No Deal BREXIT : What Would 'WTO' Mean for UK-EU trade? [online] Available at: <https://www.euronews.com/2018/12/19/how-would-uk-eu-tradebe-affected-by-a-no-deal-brexit> February 22,2019 [Accessed 20 May 2019][suggesting that the British government acknowledges that with no exit agreement in place, the EU would consider the UK "a third country for all purposes". It has published details of its own no-deal preparations. Trade rules would change from those of the European Union based on its single market and customs union - to those of the World Trade Organization (WTO).WTO rules mean each member must grant the same market access to all other members - except developing countries and those that have free trade agreements. Trade experts agree that the EU could not treat the UK differently to other states: rules currently imposed on third countries would apply.] AUTHORS NOTE: this article does not address WTO Article 24 in relation to BREXIT. 
The impact of a October 2019 BREXIT "no deal" EU departure for the UK would also extend beyond its trade with the European Union. Prior to BREXIT, Britain traded with the rest of the world as an EU member. Under a BREXIT "no deal" scenario, some 40 existing trade agreements fully or partly in place between the EU and dozens of countries would no longer apply to the UK. ${ }^{8}$ All these trade agreements and all other joint EU treaty agreements would need to be renegotiated immediately. As of June 2019, when this article went to press, there were no discussions about these trade agreements. Nor have there been any completed negotiations documented about these treaty legal rules or timelines. Nor have there any public U.K. policy papers circulated including specific economic consequences of ongoing delays. ${ }^{9}$ All of this consternation comes from within the core of the U.K as a sovereign State arising out of long-term regional alliances that are highly integrated across economic capital markets and financial systems with multilayered treaty and contractual arrangements.

As noted in the Part I of this commentary, it is the core function of the State to balance all three forms of essential capital resources [economic, social and human capital] from inside the framework of liberty and its four cornerstones. That a sovereign State seeks to retain is role as the sole architect of world order in the $21^{\text {st }}$ century, its actions must be based on mutuality and equity, reciprocity, justice and ethics, and human dignity also discussed in Part I. Diagram 01 depicts the State in a state of this proposed integrated balance. Diagram 02 depicts the State whose sole focus is aligning economic capital development and utilization. As that State becomes economically dysfunctional and capital investments become distorted, the core function of the State shifts, and it gradually moves outside the framework of liberty - leaving behind the social contract obligations for democracy and economic justice that support stability a broad civil society.

8 Ibid., "No Deal BREXIT"; [quoting that Brexiteers argue that the UK could survive EU tariffs, and that higher tariffs faced by exporters could be offset by a more favorable exchange rate created by the fall in the value of the pound. However, a report by one group of economists found that UK exports had been damaged, not boosted, since the referendum. ProBrexit economists also quote estimates suggesting that import tariffs from EU countries could generate significant revenue for the UK. But a report by the think-tank UK in a Changing Europe says revenue gains from import tariffs would come at a cost of higher consumer prices. Some no-deal economists have also claimed that the UK could unilaterally drop all tariffs, slashing consumer prices. Their critics agree that prices would come down - but, they argue, so would protection for various sectors of the economy. There've been warnings that much UK manufacturing - including the car industry - as well as British agriculture would be severely damaged by total exposure to global competition].

9 For example, The U.K. National Audit Office said in a report in October 2018 that the number of customs declarations the UK authorities need to process might rise from 55 million a year to 260 million. New border systems would be needed, but in September 2018, the U.K. regulatory body responsible reported that 11 out of 12 projects might not be ready in time. 
As noted in Part I, this distortion is evidenced in part as BREXIT-EU negotiations demonstrate little creative imagination given the politics of resentment around social capital and human capital conditions inside the State that gave rise to the 2016 BREXIT vote in the first place. These political resentments continue to fester. Theresa May's motto of "One Nation Conservative" reflects BREXIT negotiations to date that have demonstrated a cumulative and blind reliance on the ideology of linking an outdated neoliberal economic paradigm [c. 19802010] to the $21^{\text {st }}$ century principles of democracy and sovereignty as discussed fully in Part I. The context for the politics of resentment addressed by the GeoNOMOS depicts a different strategy - one that engages the "constitutional imagination" of the 27EU, harnesses and redirects the synergy of political resentment, and supports the design of a continuum for State sovereignty based on a new definition of democracy and a refocused economic direction for this century.

\section{Post-BREXIT Reintegration : The Politics of Resentment and EU Insti- tutional Challenges}

The BREXIT vote was a much deeper symptom of the ongoing challenges to democracy and individual liberty in this century. ${ }^{10}$ It was a symptom of the politics of resentment. The 2016 vote was a severe shock to Britain's political class from voters who are angry, confused and deeply distrustful of elites. BREXIT became the symptom of discontent, a culmination manifested by the politics of resentment where voters demanded the U.K. "reclaim its sovereignty". ${ }^{11}$ As the resentment peaked even London was challenged as the financial center of the world, unfettered immigration was rejected, and the neoliberal "trickle down"

10 COHEN, Roger. Britain's BREXIT Leap in the Dark. [online] Available at: <https://www. nytimes.com/2016/06/25/opinion/britains-brexit-leap-in-the-dark.html> June 24, 2016. [Pointing out that fifty-two percent of the British population was ready to face higher unemployment, a weaker currency, possible recession, political turbulence, the loss of access to a market of a half-billion people, a messy divorce that may take as long as two years to complete, a very long subsequent negotiation of Britain's relationship with Europe, and the tortuous redrafting of laws and trade treaties and environmental regulations - all for what the right-wing leader Nigel Farage daftly called "Independence Day]

11 ERLANDER, Steven. Brexit' Opens Uncertain Chapter in Britain's Storied History. [Online] Available at:<https:www.ntyimes.com/2016/06/25/world/Europe/Brexit_european-unionuncertain-charpter-in-britains-storied-history.html > June 24,2016[noting that on BREXIT that the divisions are just as much cultural as economic, raising serious questions about Britain's political coherence and unity, after such a vicious 2016 campaign; BREXIT actually exacerbated tensions within the four countries of the United Kingdom jolting long standing issues about English nationalism and its 'festival of democracy'. The Scottish independence referendum had clearly failed in 2014.In addition to intensifying demands for another referendum on independence for Scotland, the outcome of the European Union vote may also increase demands in England, which makes up 85 percent of the British population, for its own "devolved Parliament" to vote on laws concerning only England, just as Parliaments in Scotland, Wales and Northern Ireland now provide for their regions] 
economics was attacked for failing to distribute the benefits of economic wealth throughout urban and rural communities in British civil society. ${ }^{12}$ The lack of consistent U.K. domestic interventions designed to cushion the repeated blows of neoliberal capitalist globalization on citizens "left behind" was evidenced by voter anger as outlined in Part I.

Post-BREXIT, the British Treasury, the Bank of England, the International Monetary Fund and the Institute for Fiscal Studies concluded that the British economy was in for a severe shock. The Treasury estimated that the British gross domestic product, representing the size of the economy, would fall by 3.5 percent, clobbering tax receipts; that half a million people would lose their jobs; and that housing prices (and thus personal wealth of homeowners) would fall by 10 percent. ${ }^{13}$ In 2018, International banking as well as domestic corporate leaders began to increase their influence and lobbying power over U.K. political leaders for a "soft BREXIT." 14

12 Here's What Many Journalists Missed in When Covering The Brexit Vote. [online] Available at: $<$ https://www.washingtonpost.com/news/monkey-cage/wp/2016/08/04/heres-whatmany-journalists-missed-when-covering-the-brexit-vote/ August 4, 2016. [Noting that welfare states such as U.K. have had policies that helped free trade losers; pointing to political analyst John Ruggie who called this system for cushioning blows from the international economic system "embedded liberalism" and argued that the interventionist domestic welfare state made possible today's liberal trade order on a global scale. But these policies are eroding as winners are not compensating losers. In fact, private corporations that have gained enormously from globalization are using complex financial arrangements to escape taxes and wealthy individuals are doing the same. Economic inequality is increasing in a "winner-takes-all" society. Mainstream media that focuses on racism and xenophobia rather than on economic loss and inequality may not be taking into account these political policy shifts. Quoting Larry Summers who insisted in 2005 that financial markets could not fail now recognizes that the Brexit vote is a 'wake up call to elites everywhere on a need to redesign economic policy' that hears the anger expressed in the Brexit vote. The real issue in BREXIT was what did average British voter gets when and how from EU integration]

13 Supra, Note 3. See also a resource list provided in Part I of this commentary on the context for globalization of the late 20th century and the negative impact the neoliberal paradigm [c.1980-2010] for global capitalism has had on exercise of State sovereignty and State autonomy: RAMIREZ, S.A., Taking Economic Rights Seriously After the Debt Crisis, 42 Loy. U. Chi. L. J. 713, 2010 ; see also RODRIK, Dani, The Globalization Paradox : Democracy and the Future of the World Economy . New York: W.W. Norton \& Co., 2011; see MILGATE, M., STIMPSON, S.C., After Adam Smith: A Century of Transformation in Politics and Political Ideology. New Jersey: Princeton University Press, 2009; see also KRUGMAN, Paul Krugman, Trade and Wages Reconsidered. Washington, D.C.: Brookings Institute: Papers on Economics,2008; see McMICHAELS, P., Development and Social Change: A Global Perspective. New York: Sage Pubs, 2008 ; see NOLAN, P., Capitalism and Freedom: The Contradictory Character of Globalization. New York: Anthem Press 2008.

14 For the UK, the balance in negotiations will need to better reflect the demands of traditional U.K. economic and corporate trade "power brokers" who want to continue to function in the global market place as before with London as the financial center of the world, and the populist concerns in 2016 that fueled BREXIT in the first place -- that the 
The politics of resentment has its roots in many modern culture contexts but may be summed up briefly as a revolt against the current paradigm for global capitalism and the inequality of wealth distribution in its current operating systems. ${ }^{15} \mathrm{~A}$ majority of U.K. citizens in 2016 had no time for the politicians that brought the world a disastrous war in Iraq; the 2008 financial meltdown; European austerity coupled with stagnant working-class wages; high immigration; and tax havens for the super-rich. That some of these BREXIT issues reflect a tsunami of nativism and anti-establishment rage with no direct link to the European Union or its much-maligned Brussels bureaucrats did not matter. ${ }^{16}$

"trickle down" mantra of a neoliberal paradigm for globalization has not worked in the day-to-day live of UK citizens. BREXIT Part I negotiations that concluded in December 2017 did little to address these populist demands all of which will require a different type of domestic restructuring of program budgets that correct looming issues on the human capital and social capital development side of that State. None of these domestic level wealth distribution issues were on the table for the trade negotiations that were initiated with the EU in 2018 by the U.K. See BROWNE, John. UK's Minister Commits to Successful Brexit, Townhall Finance [online]. Available at $<$ http://finance.townhall,con/columnists/ johnbrowne/2016/08/05/uks-prime-minister-commits-tosuccessful-brexit-n2201876> ; see also KIRKA, Danica. UK Central Bank Tried to Soften BREXIT Shock in Economy, ABC News/Associated Press [online]. Available at $<$ https://abcnews.go.cpm/International/wiresStory/uk-central-bank-economy-brexit-stimulus-41112988> [noting that while cheaper money will help households and companies the cost of loans was already very low and is not their primary concern right now, economists say. Business in particular worried about whether to make investments or hire in Britain without knowing what the country's trade relationships with the EU will be]

15 KONCEWICZ,Tomasz. Understanding the Politics of Resentment. [online] Verfblog, 2017/9/28. Available at $<$ https://verfassungblog.de/understanding-the-politics-of-resentment/> 28 September 2017. [Accessed 22 March 2019]; See also at DOI https://dx.doi. org/10.17176/20170929-135630 [last viewed February 18,2019][noting that the resentment that is sweeping across Europe cannot simply be equated with protest, revolt, and public contestation because unlike the rising politic of resentment, these episodes reflect part and parcel of democratic process that supports an open public square; Koncewicz citing Muller, suggest that populism cannot be full equated with this growing phenomenon because the politics of resentment never really operates on its own. It is the function and mixture of culture, history and a range of domestic politics from many of the 27EU members: BREXIT anti-European sentiments in the U.K.; right wing parties in France, Germany and Austria elections spread hate speech and publicly promoted the exclusion of "the other"; and most certainly in Poland where disabling constitutional checks and balances have taken over the State. Koncewicz concludes that the rationale of resentment is distrust with varying degrees of intensity and disdain for the liberal status quo. The politics of resentment sets up a competing constitutional doctrine ('constitutional capture'] that attacks liberal democratic values with its current stigma (eg, support only for status quo) and offers an alternative to the promise of populist narratives.] See further discussion on the politics of resentment in reference to the EU proactively creating a new constitutional regime for capitalism outlined later in this discussion.

16 The U.K. initiated the divorce negotiations and activated Article 50 with the EU in March 2017.This was swiftly followed by the U.K.- EU negotiating tentative agreements for December 2017, only to became more politically divisive in 2018 with trade and tariffs, geographic boundaries of the U.K., and financial transactions issues arising as the bounda- 
The signs and symptoms of the politics of resentment reflect changes in the solidarity as discussed in Part I of the post-WWII era as evidenced by multiple global factors: [1] the sheer increase in number of recognized sovereign states since 1950, [2] the decline of traditional autocratic Westphalian notions of how a sovereign's legitimacy is recognized as more States "share" sovereignty in regional treaties, international declarations, and multi-lateral trade agreements; [3] the $20^{\text {th }}$ century rise of autocratic and oligarchic governments ; and, [4] the decimation of State domestic economies and social safety nets long considered essential components of the post war "welfare State" that have all but disappeared in the fall-out from applying the ideology of the neoliberal paradigm [c. 1980-2010] and it public austerity programs to every corner of global economy. ${ }^{17} \mathrm{~A}$ process of European unraveling started long before the 2016 BREXIT vote. A core assumption of regional and global foreign policy - that a united Europe had overcomes its historical divisions - has been undermined and perhaps changed forever as 2016-2018 national elections continued to promote populist, progressive and right leaning political parties. The wave of populism, like a tsunami swept across the Continent as the U.K., France, Austria, Italy, The Netherlands,

ries on a variety of policy directives lurked within a dense political fog. While regional issues concerning the U.K. financial, trade and tariff connections to EU institutions and the custom market were top priority for U.K.-EU negotiations well into early 2019 , the domestic issues around social and human capital programs that spurred the BREXIT vote in the first place were never addressed in Brussels. Nor were these domestic allocations of capital resources as a citizen 'social contract' priority addressed 2019 U.K. Parliament sessions at home. The fodder of the politics of resentment remained unanswered as clearly demonstrated with the public contestation and Parliament rejection of the BREXIT agreement throughout 2019 followed by no confidence votes, demands for a new referendum and contentious structural amendments to the BREXIT Agreement and Declaration that followed.

17 Without a doubt, the rapid and uncontrolled movement of private sector global capital and public sector capital and domestic finances in and out a State's legal boundaries also bears witness to these relational components of State sovereignty within the international sphere of the equation. See full discussion in Part I of this commentary that sets forth a new taxonomy for the sovereign State in the 21st century based on a framework of liberty and a defined core function of the State that continuously balances all three forms of capitaleconomic, human and social capital-and an enterprise of law that support a global community of traders. The same flexibility of global capital movement never seemed to occur on the side of development or utilization of social and human capital. While economic capital was and remains highly mobile and unregulated, most human labor [human capital] is bound by State geographic boundaries and people's life circumstances and citizenship rights are dictated by those same State boundaries. This is the domestic re-balancing that appears to be in demand to address the benefits of economic capital development and utilization across the EU that have not trickled down in accordance with the neoliberal ideology to the social settings and human capital development in places where most European citizens live their entire lives and work every day. See full explanation of these dynamics related to sovereignty outlined in Part I. 
Greece, Poland, Hungary, and Germany prompted by a rising sea of change confronted the purposes and goals of the European Union as an institution.

Following the cycle of 2016-2018 national European elections, it appeared that EU citizens were poised to send more populists to Brussels in the May 2019 European Parliament elections as well. The big center-right and center-left blocs in the European Parliament lost their combined majority amid an increase in support for liberals, the Greens and nationalists. While Pro-EU parties will remain in a majority, those traditional blocs will need to seek new EUP alliances. The European People's Party (EPP) [center-right] will remain the largest bloc but it will be pressured internally to form some kind of political coalition with the Socialists and Democrats bloc, and for the first time, with support from liberals and the Greens. This barrier becomes significant because the EU Parliament shapes legislation and determines who is selected for European Commission at its executive leadership level.

Generally, voter turnout for EUP elections was the highest for twenty years after decades of declining voter participation. According to EUP post-election reports, just under $51 \%$ of eligible voters across the 28 member states cast their ballots, compared with fewer than $43 \%$ in $2014 .{ }^{18}$ For the first time in forty year, there is a new balance of power at the EUP. ${ }^{19}$ The trends post - election point to a clear anti-establishment mood reflected as part of the "politic of resentment" that was so pervasive in national elections 2016-2018 across the Continent. A clear rejection of the status quo as evidenced in elections for Germany, Italy, Poland, Hungary and others discussed in Part I of this article is now reality in the political shift within the EUP. ${ }^{20}$

People used the EUP elections to send a strong message to their national governments as well. ${ }^{21}$ Europe's voters were clearly looking elsewhere for answers

18 European Elections: Power Blocs Lose Grip on Parliament.[online]Available at: <https:// www.bbc.com/news/world-europe-48417744> 29 May 2019 [Accessed 8 June 2019]

19 Ibid., In the UK, the 2019 newly-formed Brexit Party [Nigel Farage] claimed a big victory [29 EUP members], and a strong performance by the Liberal Democrats came amid massive losses for the traditional Conservative and Labor parties following multiple failed attempts in Parliament to finalize the 2016 voter-mandated EU divorce settlement following the 2018 EU-BREXIT negotiations. See also: European Elections: Country-by-Country Roundup. [Online] Available at: <https://www.bbc.com/news/world-europe-48420697> 27 May 2019 [Accessed 6 June 2019] [see for graphic depiction country-by-country EUP election results and maps]

20 ALDER, Katya. European Elections 2019: What Were the Clear Trends? [Online] Available at: <https://www.bbc.com/news/world-europe-48420024> 27 May 2019 [Accessed 6 June 2019] [breaks out election results by party and those election implications]

21 For example, it is not clear now in this EUP political shift, that Merkel can survive her multiple attempts at forming a German coalition after months of losses on significant regional German elections. Greek Prime Minister Tsipras was looking to dissolve his government to hold snap elections when his left wing party Syriza did not show significantly in the EUP 
and seemingly drawn to parties and "political personalities" that could better represent their values and priorities. Voters were attracted by the nationalist right groups in various countries, looking for a crackdown on immigration and securing more power for national parliaments, rather than for Brussels. These trends are noted in campaigns launched by Italy's firebrand Deputy Prime Minister Matteo Salvini and Hungarian Prime Minister Viktor Orban. Other voters clearly preferred a more pro-European alternative, like the Green Party and liberal groups, which also performed well in the May 2019 EUP elections.

The May 2019 EUP election results will make it much harder than it was in 2014 for the "pro-European" establishment to simply dust itself off and carry on as if the EUP elections have no institutional impact or require no policy changes. The previous 2014 EUP election took place shortly after the eurozone crisis, when countries were still going from bailout to bailout. The 2019 EUP election trends are complicated by the protracted battle by Germany for the Commission presidency, and the many scattered calls for a new approach. At least three populist member-state governments - Italy, Poland and Hungary - will have much greater influence than the minority of populist MEPs in the sense that these countries each will choose an EU Commissioner.

While it is likely these three States will be kept away from essential portfolios, they will nonetheless be an awkward presence in the EU, an institution that has not consistently managed handling internal dissent of these State members. ${ }^{22}$ Current 2016-2019 Commission President Jean-Claude Juncker has had the ability to manage some of the ongoing dissent since 2014 because of his

elections. Italy's right wing Salvini who espouses to the role of Italian Prime Minster may actually benefit from calling early national elections. And the trend effects BREXIT after Teresa May leaves as Prime Minister, and there is a gap in conservative BREXIT leadership. Many EU leaders who are tied up in their own national political drama will not be likely to re-open the $2018 \mathrm{EU}$ - BREXIT settlement agreement no matter who is chosen for U.K. Prime Minister.

22 MUTJABA, Rahman. Populism Tides are Rising: Euro-skeptics will Shake up Status Quo at Next European Elections. [Online] Available at <https://www.politico.eu/article/populismrising-tide-emmanuel-macron-angela-merkel [29 January 2019] [Mujtaba Rahman is the head of Eurasia Group's Europe practice][noting that right-wing Euro-skeptics have until now been kept apart by the influence of Britain's particular flavor of Euro-skepticism, as well as by strategic competition, personality conflicts and other petty disputes. While it is unlikely that a single right-wing populist group could form and overtake the center left to become the EU Parliament's second-largest political force for elections in 2019, it is not impossible. If that happens, such a group would in theory receive significant committee representation including the right to hold the presidency of the Parliament - Such a shift would probably not be granted by the rest of the Parliament pointing to a very entangled nomination process. Even after a series of discussions produce an initial College of Commissioners, "would-be" officials will be interviewed by the Parliament's committees and just as mainstream MEPs will enjoy tearing into populist nominees - Euro-skeptics will try to suggest conventional nominees are disconnected from reality] 
deliberate centralization of the institution's decision-making process. However, a weaker president than Juncker would likely struggle to keep the College of Commissioners' deliberations as harmonious and controlled. Configuring and reconfiguring the College of Commissioners will coincide with the elections and reorganization in the European Parliament itself where the demands of the politics of resentment will continue to be forcibly articulated.

None of this will make for a good start to the much-needed stability in the European Union reintegration post - BREXIT in late October 2019. As 2019 continues, the U.K. and the 27EU stand looking across a chasm created by the politics of resentment, paralyzed by these times of extraordinary challenges for both the region and the institutional need to redefine democracy for the $21^{\text {st }}$ century with a focus on individual liberty and solidarity. ${ }^{23}$ Two distinct and separate new legal and political strategies are desperately needed - one to support democracy, followed by one to redesign global capitalism. The EU Brussel's bureaucracy was a convenient BREXIT target in the U.K., but other 2016-2018 national elections cycles across Europe reflected this politic of resentment and its demand for changes as well - inevitably addressing populist feelings about State sovereignty, nationalist integrity and the need for more economic equity in designing a new paradigm for capitalist globalization. ${ }^{24}$

23 This premise was fully outlined in Part I of this commentary on the GeoNOMOS with the discussion on the State's primary function as two fold: [1] to protect participatory democracy based on affirming individual liberty ; and [2] to remain the primary architect of world order by supporting by an international community of States. See footnotes in Part I that lists references on the populism and issues that defined the 2016-2018 cycle of national elections across the European continent.

24 The legitimacy of the neoliberal paradigm [c. 1980-2010] for the globalization process has increasingly been challenged following the 2008-2012 global recession and as global financial institutions were forced to wrestle with the regulatory boundaries of a global market, the growing/ongoing financial and political instability of State governments[Greece, Italy, Spain, Egypt, Ireland, Portugal and more] ; equity issues in the global political economy, and the growing demands to create a more humane paradigm for capitalist globalization. A partial resource list on the context for globalization of the late 20th century along with the negative impact the neoliberal paradigm (c.1980-2010) for global capitalism has had on exercise of State autonomy: RAMIREZ, S.A. Taking Economic Rights Seriously After the Debt Crisis. 42 Loy. U. Chi. L. J. 713, 2014; see Part I for this Commentary for a full discussion and reference list concerning the negative impact of the neoliberal paradigm [c. 1980-2010] on the function of State sovereignty. 


\section{At The Crossroads: ReDefining Democracy; Creating A New Constitu- tion for Capitalism}

The European Union appears more vulnerable in 2019 than at any point since its inception. The travails of the euro, the tide of immigration (both within the European Union from poorer to richer members and from outside countries), and high unemployment have led to widespread political resentment across Europe, including a collective loss of patience, and a weaning memory of a common good based on prosperity and solidarity. The populist waves of citizen resentment demonstrated at the ballot box are translating the European political landscape, shaking the very democratic foundations and governance priorities from within the institutional integrity including the "rule of law" framework for European Union itself. ${ }^{25}$

The Europe to emerging from the MEP election process in late May 2019 and the looming BREXIT October 2019 departure will be on shaky ground. With Theresa May gone to manage the transition of BREXIT, German Chancellor Angela Merkel in succession mode in Berlin, and Macron facing a state of national emergency on economic and jobs policy, Europe's most powerful champions are more introspective than ever before. Meanwhile, Italy, Greece, and much of Eastern Europe are in the hands of politicians who want to "take-

25 UITZ, Renata. The Return of the Sovereign: A Look at the Rule of Law in Hungary-and In Europe. VerfBlog, 2017/4/05.[Online] Available at: <https://verfassungsblog.de/thereturn-of-siveireignty-a-look-at-the-rule-of-law-in-hungary-and-in-eruope $>4$ May 2017 ;also at DOI: https://dx.doi.org/10.17176/20170405-130326. [Accessed 21 January 2018] [discussing the National Consultation direct mail in 2017 designed to survey citizens on 'issues of national importance, trying to demonstrate a strong manifestation of support for Hungary's independence; noting that there needs to be a closer debate over how legal rules are envisioned in a rule of law framework that looks at necessity and proportionality and concluding that these shifting political and legal dynamics have significant relevance - if the $\mathrm{EU}$ is be a beacon of light for rule of law and human rights when it very foundations are being shaken]; see also PECH Laurent, SCHEPPELE,Kim Lane. Poland and the European Commission, Part III: Requiem for the Rule of Law, VerfBlog, 2017/10/03 [Online] Available at: <https://verfassungblog.de/poland-and-the-european-commission-part-iii-requieum-for-the-rule-of-law $>$. DOI: https://dx.doi.org/10.17176/202170303-131734. [last reviewed October 18, 2018] [discussing the EU attempts to address the systematic attacks on the rule of law, and its 'annual rule of law dialogue' that has been operational since 2014; noting that although the EU Council's annual dialogue has at its purpose to promote and safeguard the rule of law through a more evidence based approach, this process has yet to focus on unifying Member States shared values; pointing out that in its published EU Council summary documents in 2016, the Council leadership laments the EU's members national government inability to address the backsliding and the denial of the urgent need to address democratic values and the rule of law; reporting how one State did recommend an annual peer review process in 2016 ( see EU Council document no.13230/1/16) and one State outlined the need for a more defined mechanism to support the EU Commission and EU Parliament so the existing rule of law documents could be incorporated into a more coherent framework including a permanent State monitoring mechanism but neither recommendation was taken up as part of the 'annual rule of law dialogue' process]. 
back" power from Brussels. Add a more divided European Parliament into the mix, and it seems the EU is heading toward a more fragmented future where populist's definitions of legitimate expressions of sovereignty and a demand for a new paradigm for capitalist globalization will simultaneously be on the negotiating table.

Koncewicz and Hamulak speak to questions of institutional integrity within the European Union. Koncewicz outlines "constitutional capture" asking whether those at the heart of European disintegration with their deafening passivity that "this will never happen to us", have actually lost both their political leadership and the 'constitutional imagination' required to rise to the complexity of this occasion given its potential and real negative implications on the underlying $\mathrm{EU}$ treaty revisions that will be needed ${ }^{26}$ Hamulak discusses the internal EU Treaty as a "federation of States" or a heterarchy, that will require a more dynamic institutional engagement along a continuum of where questions concerning sovereignty must be answered for this century. ${ }^{27}$

The creation of a re-integrated E.U. follows the new engagement demands of heterarchy in the transition period [2019-2021] which will not be an easy one

26 Supra, Note 15, KONCEWICZ [suggesting the EU is now being faced with the "constitutional capture" that has been elevated to new constitutional doctrine so much so that the challenge of "Doing Europe" with its overlapping consensus and tolerance of 'the Other' has never been both so active or so dramatic - the idea that "this will not happen to us" is no longer an option - in his conclusions, he wonders will the EU finally tune in and listen? Member States are key players in the European Union [EU] and while the EU does have some "state-like" features, it is not legally acting as a nation State in the traditional sense of sovereignty and international law as it operates under the auspices of a treaty agreement and not a Constitution] This author notes that it is the ability of member States in the EU to amend the Treaty that will remains an important sign of political and legal preservation of the sovereign position of member States as the EU moves into the 2019-2021BREXIT transition. Furthermore, this idea of "reciprocal flexibility", or, of each State's supervising function of the EU Treaty Agreement, can be read to mean there is also a possibility of negative Treaty revisions beginning in 2019 that might be drafted and could seriously limit or change the competence that EU member States currently have accorded to the EU as a regional institution.

27 HAMULAK, Ondrej. National Sovereignty in the European Union - View from the Czech Perspective. Cham, Springer International, 2016, at 47-51.[outlining a detailed summary of the sovereignty issues within the EU that will require an intentional level of engagement citing McCormick, Walker and others, that in order to deal with new legal realities that arise in the supranational organization, one will need a lot of legal imagination; offering an in depth analysis of sovereignty suggesting two approaches : the static perceptions of sovereignty based on notions of Westphalia, and the dynamic approach that rests on postWestphalian notions where sovereignty and authority are understood as non-exclusive ideals so much as that such an understanding does not imply loss of State autonomy ] This author notes that the EU Constitutional systems is very complex and there will need to be more open engagement and public conversations in order to address growing populist and EU accountability concerns of member States as they collectively seek to secure the operational future and integrity of the EU post BREXIT 
for the U.K. nor for the European Union. The remainder of 27EU will be forced to reconsider its own range of member interconnectedness to the EU's heterarchy [model of "shared sovereignty]. ${ }^{28}$ This reintegration of EU internal political partnerships will need to redefine democracy and solidarity as well as adjust legal commitments and Constitutional competence accorded to the EU for an entire range of matters that fall into the core function of the State [eg, management of its essential resources of economic capital, social capital, and human capital ] in support of participatory democracy designed to protect individual liberty. The implications for human rights; national and regional security; the environment and climate change; financial, tax and economic capital planning systems within the regional bloc will all be affected..$^{29}$ The key to successfully managing this dynamic is a balanced engagement between the $\mathrm{EU}$ and its institutional support for the core function of each and every nation State - and less on building and securing Brussel's bureaucracy. [Diagram 01] Shared sovereignty models support regional operations but only if the nation State is secure at its core function within the framework of liberty.

If the nation State is to remain the primary architect of world order, then two matters need to be addressed. First, the EU as a facilitator of the partnership of nation States, will need to structurally update its regional bureaucracy, define concepts of solidarity and democracy based on modern demands, track economic capital and wealth accumulation across its regional boundaries, and intentionally target rules of law and policy change on migration and unemployment throughout $2020 .^{30}$ This shift moves the EU beyond the doctrinal dysfunc-

$28 \mathrm{Ibid}$., Hamulak [outlining a detailed summary of the sovereignty issues within the EU noting that the numerous coexisting legal systems and power networks challenge the nature of sovereignty but does not mean that EU member States have no sovereignty; painting a new "grey zone" where sovereignty is treated as a "category" and when EU reintegration occurs there are going to be changes; analyzing the notion of 'late sovereignty' which better aligns with the countries who have only recently in the late 20th century come out from under the Brezhnev Doctrine, and thus, State sovereignty and autonomy are more accentuated by these member States who are more careful about any weakening of their State sovereignty]

29 Within the structures of the EU, even if Article 50 proceedings make a secession of a member nation-state essentially de jure possible, we suggest that such a step is de facto impractical and perhaps imprudent within the context of a GeoNOMOS model as set forth in Part I of this Commentary; and also otherwise, because it would tend to cause a potential ripple effect which might lead to an unraveling and disassociation of the whole, regardless how great its other resources and forms of capital might be. A region which had shown in history its own weaknesses in co-existing as separate, independent nation-states, where war had raged after war for a long period in history, had, for a period in time, tried to learn how not only to co-exist as one large system of governance, only to return to the old ways of "separate, but equal".

30 Supra, Note 25, PECH, Laurent, SCHEPPELE, Kim Lane.[addressing the EU Council's 'annual rule of law dialogue' and summarizing recommended changes in the scope and function for that process ; One realistic beginning point for the EU could very possibly includes procedural upgrades in the already existing EU peer review system with concrete 
tion or "constitutional capture" of its current bureaucracy to a more responsive and empowerment infrastructure. ${ }^{31}$ Second, a new legal constitution for capitalism will be written, one that models the rule of law with a framework of liberty designed to strengthen the State core function and its enterprise of law. ${ }^{32}$ This end result occurs not by dictating outdated neoliberal ideology and market principles, but by creating a more integrated rule of law. This rule of law recognizes the partnership between the EU and the core function of the State as the only partnership which best addresses new demands in the marketplace along the horizontal axis [Diagram 01].

The GeoNOMOS depicts a continuum of State sovereignty outlining the core function of the State in Diagram 01 as it operates along a vertical axis which engages domestic level issues and simultaneously along a horizontal axis which engages international level issues and activity. ${ }^{33}$ All State activity simultaneously must function at the center of these two axis points, and within a Framework of Liberty, by continuously balancing the three capital resources [economic, social,

time-sensitive and established monitoring guidelines including real-time enforcement processes.

31 KANTER, James. Far Right Leaders Hate EU Institutions But Like Their Paychecks. [online]. Available at <https://www.nytimes.com/2017/04/27/world/europe/> 27 April 2017 [noting that many alt-right candidates who despite the EU institution use the European Parliament as a protest platform and collect salaries of around \$ 100000 Euros, a generous per diem and an annual staff and office budget in excess of 340000 euros. So while working to blame the European institutions for being onerous bureaucracies with no democratic accountability they also seem to enjoy the lavish perks of the office while they shun the daily grind of legislative work, miss votes, mock democratic processes on behalf of the EU. Marie Le Pen opposition presidential candidate in France, is a member of the European Parliament but has been stripped of her immunity several occasions due to fraudulent activities. Similarly, Nigel Farage form the UK who also was a member of the European Parliament and was leader of the U.K. Independent Party until 2018. There are calls of reform for European Parliament elections to be held in March 2019 so that candidates who run must support the democratic process and human rights values of the EU institutions the Parliament seeks to support]

32 NIB, J. EUs Juncker Hails Macron. [online]. Available at https://jonnib.wordpress. com/2017/09/26/eus-juncker-hails-macron-speech-as-very-european. 26 September 2017.[Accessed 18 October 2018] [suggesting that the Euro-zone will need its own budget and finance minister; wanting to address the divisions between EU richer countries in the West and poorer States on the eastern side of the Continent]; NOTE ALSO: European Commission President, Jean-Claude Juncker has already called for a EU Summit in early 2019 to detail and tackle the programs that will be re-designed after March 2019 when the U.K. begins its 2019-2021 transition period.

33 A continuum is referenced as the basis of this new typology for sovereignty because it represents a more flexible set of options given the range of possibilities in terms of how an individual State interacts with some sense of legitimacy on behalf of the people it is governing and interacts as a member of the international community of States; there is no limit to the possibilities offered as part of this proposal for a continuum of State sovereignty so long at it operates within a framework of liberty. See diagram and discussion detailed in this commentary. See definition of continuum at http://merriam-webster.com 
and human] - essential resources which all States possess to varying degrees. ${ }^{34}$ Other non-state actors and international corporate entities that engage from within the State must also abide within the Framework of Liberty and its enterprise of law. In this way, the four cornerstones of the Framework of Liberty [justice, equity, individual choice, and individual capability/resource development] are consistently incorporated to support EU regional democratic and defined values of solidarity such as reciprocity, mutuality and human dignity. ${ }^{35}$

Correcting existing distortions in economic capital and any State overreliance on its acquisition, include two points where policy designers can begin to think about reintegration. First, a brief discussion provides confirmation of the

34 At the same time, with a focus on economic capital development and utilization, the author begins to outline the struggles at the level of the nation State as it begins to adjust to a more integrated model of capitalism that balances economic capital at its core function with equal measures of financial, policy priority and broad political support for the development and utilization of human and social capital. See also, RODRIK, Dani. The Globalization Paradox: Democracy and the Future of the World Economy. New York: W.W. Norton \& Co., 2011; pp 231-242, 245 [discussing a dominant role for the nation State in relation to the principles of democratic decision-making which is the foundation for the international economic architecture; noting that when States are not democratic this scaffolding collapses and one cannot presume a country's institutional arrangements reflect the preference of its citizens]; See also RODRIK, DANI, The Fatal Flaw of Neo-liberalism [Online]. Available at https://www.theguardian.com/news/2017/nov/14/the-fatal-flawof-neoliberalism-its-bad-economics. [November 14,2017] [Noting Neoliberalism and its usual prescriptions - always more markets, always less government - are in fact a perversion of mainstream economics. Rodrik suggests that there is nothing wrong with markets, private entrepreneurship or incentives - when deployed appropriately. Their creative use lies behind the most significant economic achievements of our time. He notes as "we heap scorn on neoliberalism, we risk throwing out some of neoliberalism's useful ideas. The real trouble is that mainstream economics shades too easily into ideology, constraining the choices available and providing cookie-cutter solutions. A proper understanding of the economics that lie behind neoliberalism would allow us to identify - and to reject - ideology when it masquerades as economic science. Most importantly, it would help to develop the institutional imagination badly need to redesign capitalism for the 21st century"]; see generally MILGATE, M.,STIMSON, S.C. After Adam Smith: A Century of Transformation in Politics and Political Ideology. New Jersey: Princeton University Press, 2009

35 The responsibility for securing the four cornerstones that anchor the framework of liberty rest with the State. The State affirmatively creates conditions within its domestic jurisdiction [vertical axis] where justice [ethics] and equity prevail as reflected by these two anchors located on the lower portion of the liberty framework. [see diagram] When the conditions for justice and equity occur routinely as part of the State's single core function and operate in meaningful and consistent way within a domestic jurisdiction, then individual autonomy as an expression of human dignity [comprised of individual choice and individual capability/resource development] is supported and actively anchored by the two cornerstones on the upper half of the framework of liberty. Thus, the partnership depicted by the social contract between a "caring" State and its people [depicted by the vertical axis] and based on the universal principle of mutual benefit, operates as the State's single core function, exists inside the framework of liberty, and continually reflects the operative and proscriptive components in support of the principle of human dignity 
ongoing demise of the neoliberal paradigm [c. 1980-2010] for capitalist globalization. The need for a new "rule book" for economic capital [the new legal constitution for capitalism] embraces Piketty's definition of capitalism as a "dynamic legal system that continually transforms society, its social relations and its socioeconomic order" ${ }^{36}$ Piketty and other scholars who care about democracy, outline the basic principles of justice and equity [cornerstones on the GeoNOMOS Framework of Liberty] pointing to imbalances in the current global socio-economic order evidenced by the growing wealth inequality and distorted income distribution. Second, they offer several responsive options for a new legal constitution for capitalism that could be coupled global and regional tracking mechanisms on wealth and work in tandem to build a more responsive EU institutional reintegration post-BREXIT for this century. ${ }^{37}$

According to Grewal and others, the first legal constitution for capitalism was based on the rule of law as it was designed historically and then codified to support colonialism in the past. ${ }^{38}$ For a modern EU interpretation using the term

36 BOUSHEY, Heather, DELONG, J. Bradford, and STEINBAUM, Marshall [eds], After Piketty: The Agenda for Economics and Inequality. [Cambridge, MA: Harvard University Press, 2017.]

37 PIKETTY, Thomas. Capital in the Twenty-First Century, trans Arthur Goldhammer [Cambridge, MA: Belknap Press of Harvard University ,2014] see specifically other tools Picketty discusses such as the World Wealth Income Database and the Global Wealth Register as supportive E.U. mechanisms in designing a peer review monitoring and enforcement system for member State partners. These ideas will be contested and rightly so - it is one way to begin to address the well documented and ongoing economic capital demands, unemployment, sluggish growth, and wealth disparity].; see also DAVIS, M and MONK, D.B.[eds. Evil Paradises: Dreamworlds of Neoliberalism. New York: New Press, 2007 ; see OXFAM, Working for the Few: Political Capture and Economic Inequality [Oxford: Oxfam International, 2014; see SOSKICE, D. Capital in the Twenty First Century: A Critique, British Journal of Sociology, 65, No.4[2014[650-666]; see STIGLITZ, J. Free Markets and the Sinking of the Global Economy [London: Allen Lane,2010]; see HARVEY, D. The Enigma of Capital: And the Crisis of Capitalism. London: Profile Books, 2011.

38 GREWAL, David. The Legal Constitution of Capital. In BOUSHEY, Heather, DELONG, J. Bradford, and STEINBAUM, Marshall [eds], After Piketty: The Agenda for Economics and Inequality. Cambridge, MA: Harvard University Press, 2017.] pages 470-491.[Grewal suggests that this "constitution of capitalism" has a double meaning. First, it reflects the constitutional order that has been adopted by most capitalist societies. The question is whether citizens have a constitutional right to live in a society free of monopolies or what is referenced often as "crony capitalism. This is not the first century where "trade monopolies" have caused revolutions. Perhaps it is time to rethink economic liberty in relation to the legal analysis, eg, rational basis review of times past and to incorporate new 21st century standards for economic liberty and definitions of "monopoly" that reflect the tremendous private accumulation of economic power across the globe so as to prevent legislation that create global or State economic castes or economic classes of citizens.] AUTHOR's NOTE: The bargain underpinning the $\mathrm{EU}$ is that compromises in national sovereignty through accession to EU regulatory compliance will bring economic and social benefits. So, creating a common economic market that could rival the American economy would be a boost to lift all boats. Yet while greater access to markets and labor migration accelerated 
"constitutional imagination" as suggested by Koncewicz, a more relevant constitution for capitalism designs and structures the rule of law, definitions of democracy, and conflict resolution for the remaining $27 \mathrm{EU}$ post-BREXIT in 2019. ${ }^{39}$

As the beginning for constructing a new paradigm, the rule of law [constitution for capitalism] is designed first and foremost to support the underlying mission and affirmative duty of the nation State - to secure participatory democracy based on individual liberty. This "new choice set" is followed by creating a $21^{\text {st }}$ century economic model / paradigm for capitalist globalization - one that moves beyond the permanent coupling of an older definition of "liberal democracy" with capitalist politically elite groups as evidenced in the neoliberal paradigm [c. 1980-2010] which has functioned ideologically to serve primarily private sector capitalist globalization. The "new choice set" based on the GeoNOMOS core function of the State points to a global compact in the marketplace that is more reflective of the "common law for humanity" and, in a more straight forward manner, legally addresses how wealth distribution can exist in civil society designed to support democratic principles. ${ }^{40}$

These intentional approaches would correct and reverse what is much more evident over the last forty years where the rule of law has been seen as constantly [and rather ineffectively] chasing after the current neoliberal paradigm [c.19802010] in support of private sector capitalist globalization rather than affirmatively setting the foundation of legal rules followed by the creation of a paradigm for globalization based on a new legal constitution for capitalism. The European Union is already at this 'constitutional crossroad' no matter how daunting the

within the EU, EU mandated public austerity measures produced cutbacks in domesticlevel social programs, education and health. These public austerity measures are now at the forefront of domestic political review as evidenced by the politics of resentment and in a growing internal dispute with Member States, eg, Italy, Spain, Greece, Poland and Hungary. For many working people, the benefits of EU membership did not appear to outweigh the stagnation and perhaps even decline in the quality of life they experienced, combined with the loss of economic security.

40 The basis of a "common law of humanity" emerged after the end of the Cold War in the 1980's followed the emergence of independent States in Eastern Europe who were active in the United Nations and demanded equity and fair access into the global marketplace and international finance as well. The World Trade Organization was created in1995 as an evolution of the multilateral General Agreement on Tariff and Trade [1948]. These global trading contractual agreements between States coupled with many regional trade agreements in the late 20th century continued to erode the Westphalian notion of an absolute form and unilateral expression of State sovereignty. However, while cooperative behavior increased between sovereign States and seemingly eroded the authoritarian and more traditional Westphalian model of sovereignty, the endorsement of equality among sovereign States is also foundational to the United Nations Charter and other global institutions such as the International Monetary Fund, the World Bank, and the World Trade Organization. 
dynamics of BREXIT may turn out or how demanding the persistence of the politics of resentment. ${ }^{41}$

\section{The Public Square of Democracy As A Transformative Legal System}

That international private sector as well as international public sector trade and capital investment should be a means to an end, not an end in itself is not a radically new idea. ${ }^{42}$ As Rodrik and others have noted, capitalist globalization should be a legal instrument for achieving the goals that each State's civil society seeks: prosperity, stability, freedom and quality of life. ${ }^{43}$ This is the core thesis of the GeoNOMOS as it functions to serve as a continuum for sovereignty within a framework of liberty.

The definition of the democracy done for this century separate and distinct from the market dynamics of capitalism means that the EU as an institution ensures consistent State access to economic capital development and utilization without neoliberal ideology or entangled constraints including but not limited to the EU's historical and consistent use of severe pubic austerity programs. The empowerment of a EU "collective imagination" could establish as one of its guiding principles, a foundation for a new legal constitution for capitalism that regulates capital and global tax schematics for the entire region. ${ }^{44}$ Creating a legal constitution for capitalism also would require a legal enterprise that restructures

41 Supra, Note 37, PIKETTY.

42 RODRIK, Dani. The Globalization Paradox: Democracy and the Future of the World Economy. New York: W.W. Norton \& Co., 2011; pp 231-242, 245 [noting that it is time to move beyond the neoliberal paradigm; setting out a series of statements in support of a State's right to protect their owns social arrangements ,regulations and institutions; and suggesting that trade is a means to an end, not an end in itself so that globalization should be an instrument for achieving the goals that a society seeks: prosperity, stability, freedom and quality of life ]; see generally MILGATE, M.,STIMSON, S.C. After Adam Smith: A Century of Transformation in Politics and Political Ideology. New Jersey: Princeton University Press, 2009.

43 Ibid., RODRIK at 237-239 [setting out a series of statements in support of a State's right to protect their owns social arrangements, regulations and institutions; and suggesting that trade is a means to an end, not an end in itself so that globalization should be an instrument for achieving the goals that a society seeks: prosperity, stability, freedom and quality of life]; See also TIROLE, Jean. Economics for The Common Good. New Jersey: Princeton University Press,2017; [outlining the moral limits of the market at pp 33-50; creating a modern State at pp 155-169, and addressing the challenges to EU function at pp 265-289]; see also BOUSHEY, Heather, DELONG, J. Bradford, and STEINBAUM, Marshall [eds], After Piketty: The Agenda for Economics and Inequality. Cambridge, MA: Harvard University Press, 2017.

44 HONT, I., KAPOSSY, B. and SONENSCHER M. Politics in Commercial Society [Cambridge, MA: Harvard University Press, 2015; see OXFAM, Working for the Few: Political Capture and Economic Inequality [Oxford: Oxfam International, 2014]; see also Supra, Note 37, SOSKICE at 650-666; See also ZUCMAN, G. The Hidden Wealth of Nations. [Chicago: University of Chicago Press,2015; See REICH, R. Saving Capitalism: For The Many, Not The Few. New York: Knopf, 2015. 
the affirmative role and duties of public governance over commercial activity so that capitalism becomes more of a transformative or dynamic legal system with implications for supporting democratic social contracts in civil society which in turn, simultaneously protects individual liberty and human rights.

Piketty in his 2017 "Capital in the $21^{\text {st }}$ Century"45, and many subsequent reviewers of his work, incorporate a range of economic, legal, and interdisciplinary political ideas. Piketty has forever changed the nature of economic modeling, statistical analysis, and its implication for State level economic capital management and wealth distribution. ${ }^{46}$ As such, Piketty's very definition of capitalism as a dynamic legal system supports the continual transformation of society, its social relations and its socio-economic order. By necessity and implication, this transformation also redefines the three essential capital resources at the core of every State. [Part I outlined these definitions]. These debates will more openly define and address the expanded legal constitution for capitalism, first, as a "socioeconomic system" based on the rule of law [and not just an economic model] and second, as an "operation" that has an autonomous macroeconomic dynamic function that one State acting alone cannot possibly impact. Piketty's study really is one of "modern" inequality documenting where there is a widening difference in income and wealth among people of equal juridical standing. ${ }^{47}$ This disparity among people of equal juridicial standing is a new and primary challenge for defining democracy in this century.

The historical inequality that is often produced by market-driven societies was never doubted even by traditional political economists. Even Adam Smith in his moral sentiments around The Wealth of Nations compared Europe's rich and poor with ancient primitive society. ${ }^{48}$ There is also ample historical discussion about how reliance on the market might produce more equality so long as market activity first and foremost is based on mutual respect between contracting

45 Supra, Note 37, PIKETTY

46 KRUGMAN, P. Why We're in a New Guilded Age. In BOUSHEY, Heather, DELONG, J. Bradford, and STEINBAUM, Marshall [eds], After Piketty: The Agenda for Economics and Inequality. Cambridge, MA: Harvard University Press, 2017.] pages 60-75; 61-63 [suggesting that the tracking of concentrations of income and wealth has revolutionized our understanding of long term trends in inequality; noting that Piketty research indicates we are not just on the path to 19th century levels of inequality, we are on the path of patrimonial capitalism where the commanding heights of the economy are not controlled by talented individuals but by family dynasties; and since 1980's a large amount of the economic gains went to the top end of the income distribution with families in the bottom half lagging behind; Krugman attributes the level of uneven distribution to government action related to tax policy and income transfers.]

47 Supra, Note 37, PIKETTY

48 SMITH, Adam. An Inquiry Into the Nature and Causes of the Wealth of Nations 1.1, London: Publisher William Strahan, 1776 ; See also ROTHSCHILD, E.. Adam Smith and Conservative Economics. Economic History Review 45[1992]: 74-76 [for an account of Smith's renown as a social radical in his lifetime and the posthumous changes in his reputation] 
agents and not on the deep fissures of competitive imbalance and market distortion that is most evident today in the global marketplace. ${ }^{49}$

Piketty suggests that even the post-World War II models of prosperity that moderated the wide gaps in economic inequality were in fact an exception rather than a trend long term trend for capitalism. Just as that post-War trend that supported the construct of a "welfare State" was leveling off, the restructure of the marketplace and capital accumulation entered into the neoliberal paradigm [c. 1980-2010] pushing an "economic theory" that evolved rapidly into a political ideology for capitalist globalization. ${ }^{50}$

With the rapid shifts in the current paradigm for capitalist globalization and the demise of the nation State as outlined in Part I of this commentary, Piketty's work points to the necessity for re-engaging the legal matters of inequality and designing the transition away from the neoliberal paradigm [c. 1980-2010] for capitalist globalization. ${ }^{51}$ The neoliberal paradigm [c. 1980-2010] which grew out of an ideology called the Washington Consensus started as an economic theory of the 1980's and gradually became a "political ideology" applied worldwide without consideration of its negative implication both on State sovereignty and on the destruction of civil society's institutions of democracy. ${ }^{52}$ The International

49 WOOD, A. The Free Development of Each [Oxford: Oxford University Press, 2014], 252273 [providing careful study of the emancipatory and egalitarian aspirations of Marx thought]; MAINE, Henry. Ancient Law[1936]; Chapter 5 [suggesting that social emancipation of citizens movement from "status to contract"; economic inequality was not capable of being based on formal consensual contractual relations]; see MARX, Karl, Capital, vol 3, ch. 13 [discussing increasing capital where profit is generated through the extraction of labor; as the ratio increases by squeezing "living" capital out of the system]; Others like John Stuart Mills and Karl Marx argued that organization of production and distribution of wealth has to be reviewed more as political issues so that settings already transformed by commerce it was politics that would suggest more fair socio -economic arrangements with any given society.] To assume that designing a new economic paradigm for capitalist globalization must remain free of all discussions concerning fairness, reciprocity, mutuality and morality is rather nonsensical given the full integration currently observed in the global marketplace.

50 See Part I of this commentary for a full and detailed list of resources and ideas concerning the implications of the neoliberal paradigm and it ideology

51 Supra, Note 38, GREWAL, 476

52 Many times the policy imposition at the regional and international levels push aside or "condition" global and regional financial capital and foreign investment on limiting the full exercise of State sovereignty at the domestic [vertical axis] where priorities for social capital, public assets and safety nets, employment and local human capital development issues are contractually forced into the marketplace or are mandated to be legislated to the sidelines within the State government structures in favor of dominance by forces viewed by many States as operating outside the State's vertical axis and strictly viewed as an evil necessity for international engagement along the horizontal axis. Furthermore, the key issues surrounding these mandatory State level "structural adjustment programs" demanded by non-State actors do not always align within the justice and equity cornerstones of the Framework of Liberty or the participatory democratic foundations of the GeoNOMOS as 
Monetary Fund concludes that one can no longer whole heartedly support this neoliberal ideology $y^{53}$ for capitalist globalization given the lack of sustainability and the generated systems inequality that results when economic capital for growth dominates over any other capital objective [eg, human capital or social capital] at the core function of the State. [See Diagram 02] Rodrik argues that these negative implications happened because policy planners and political elite thought that domestic institutions could eventually "catch up" to the neoliberal dynamic. Rodrik and other researchers viewpoints were highlighted in Part I.

This divergence that Piketty discusses between return on capital and the average growth rate is a formula all sovereign States consider simultaneously at the crossroads of their respective domestic/ vertical axis and their international/horizontal axis in the GeoNOMOS. This dynamic evaluation process exists because each of 27EU partner States also has a State civil society that consists of global traders who also must operate within an enterprise of law inside the framework of liberty. But as noted by Grewal, all these matters related to an enterprise of law can be designed and codified, and, included in the new legal constitution for capitalism within the GeoNOMOS framework of liberty. It becomes the enterprise of law that functions inside the framework of liberty for every nation State.

It is at this intersection inside the State core function where the vertical axis meets the horizontal axis that creates the scaffolding for a new legal constitution for capitalism. This is the crossroads where the increase in accumulation of economic capital in all its forms continues, and where the concentration of the private ownership of capital continues to grows - both at the State's domestic level along the vertical axis where most people are bound geographically and will

outlined in Part I of this article. This Commentary is not focused on some grand macroeconomic theory or market dynamic strategy. It is the web of politics and certain constitutional regimes that result in the continued dominance of capital over the rest of the State's core function as set out in the GeoNOMOS continuum. This is why a legal constitution for capitalism would be so beneficial.

53 OSTRY, Jonathan, LOUNGANI, Prakash, and FUCERI, David, Neoliberalism Oversold, Finance \& Development, June 2016, Vol 53, No 2 [Online] Available at <https://www. $\mathrm{imf}$.org/external/pubs/ft/fandd/2016/06/ostry.htm>, June 2016. [noting that instead of delivering consistent growth, neoliberal policy has increased inequality and jeopardizes growth at the State level; while there are aspects of the neoliberal agenda that have not delivered as expected, this report's assessment of the agenda is confined to the effects of two policies: removing restrictions on the movement of capital across a country's borders (so-called capital account liberalization); and fiscal consolidation, sometimes called "austerity," which is shorthand for policies to reduce fiscal deficits and debt levels. The report outlines these specific policies and reaches disquieting conclusions: The benefits in terms of increased growth seem fairly difficult to establish when looking at a broad group of countries. $\neg$ The costs in terms of increased inequality are prominent. Such costs show the trade-off between the growth and equity effects of some aspects of the neoliberal agenda. Increased inequality in turn hurts the level and sustainability of growth. Even if growth at any cost remains as the only main purpose of the neoliberal agenda, advocates of that agenda now need to pay attention to the distributional effects.] 
remain, work and live for most of their lives, and at the State's international level along the horizontal axis where States routinely intersect with private and public international entities in the marketplace and beyond.

The scope of $21^{\text {st }}$ century sovereignty and its legitimate expression as outlined in the GeoNOMOS reflects the "public square of democracy" where the European Union must strive to redefine and reintegrate the core values of participatory democracy and individual liberty, not based on ideals defined from centuries gone by, but reinvigorated by the demands of the $21^{\text {st }}$ century. The legal empowerment of this new State level scaffolding is essential. Application of an outdated neoliberal economic ideology to this democratic scaffolding can no longer meet the growing politics of resentment. The legal constitution for capitalism begins to redefine democracy for the $21^{\text {st }}$ century not based on a "welfare state" model from World War II or a model of "illiberal" democracy yet to be defined, but based on the new cornerstones of solidarity, mutuality, reciprocity and human dignity. These are the cornerstones depicted in the GeoNOMOS model that anchor the framework of liberty.

Politics create markets and right now markets create rules of law instead of the other way around - the foundations in the rule of law are created first, and guides and monitors markets and global wealth accumulation. Governments are a major player in shaping the $21^{\text {st }}$ century public square of democracy because governments impose taxes and provide social insurance which are key components for taming capitalism and allowing democracies the freedom to achieve their best purpose..$^{54}$ Literature on different models of capitalism focus on the mechanisms public institutions use to shape income distribution across countries and how these policies shape inequality whether it is tax policy, regulatory policy, labor market policy or financial regulation policy. The politics that shape markets are intertwined with economic capital, its creation and its utilization. Two primary concerns for EU review post-BREXIT are documented by Piketty.

First, Piketty 's text cracks opens up this debate because his research suggests economic capital concentration occurs consistently across diverse types of private sector capitalist regimes. ${ }^{55}$ This means that an affirmatively, more engaged,

54 Supra, Note 37, Piketty, 474-480 [statistically documenting the role of the "social state" and the role of government in the production and distribution of wealth in the 21st century and what type of social state is the most suitable for this time]

55 Ibid., Note 38,Piketty at 1-20, 529 [noting that capitalism has its own fundamental logic and it automatically generates arbitrary inequality that radically undermine the meritocratic values that democracies are built upon; tracing the rise in inequality in wealthy countries as depicted in the share of income claimed by the top one percent which is not economically useful because it is not increasing economic growth; suggesting the political economy of Capital is a deeply traditional view of the interaction between economics and politics]; see ACCEMOGLU, Daron and ROBINSON, James Robinson, The Rise and Decline of General Laws of Capitalism, Journal of Economic Perspectives 29 [2005]: 3-28 [noting that Uzbekistan and Switzerland have private ownership of capital but these two 
transparent, and legally defined public government function at the core of the State will be required as a foundation is built for a new legal constitution for capitalism. Such an approach would secure participatory democracy and ensure individual liberty is more soundly protected.

The institutional operations of the European Union and the socioeconomic systems influenced by the $27 \mathrm{EU}$ State partners are no different - they have tremendous impact of the rule of law in relation managing and redefining capitalism as a force for good. Power internal to the EU is very fragmented and usually authority is broadly dispersed resulting in weak public sector administrative and enforcement function, divided public authority roles, leaving the EUP political parties without programmatic agendas whose members are very vulnerable to special interest group pressures. In the specific case of the EU Parliament, various MEPs may and often do not publicly support democratic values, solidarity and multi-pluralism purposes upon which the EU was founded. ${ }^{56}$ Jacobs argues it is this fragmentation that magnifies the power of wealth, aggravates the politics of resentment, and further complicates the power and influence that wealth has on policy, thus perpetuating a cycle of economic inequality and preventing a new legal constitution for capitalism from being drafted and implemented. ${ }^{57}$

Second, the laws of capitalism as outlined by Grewal and others demonstrate the continued dominance and unregulated nature of economic capital [both its development and utilization ] in liberal-democratic societies. ${ }^{58}$ One significant $21^{\text {st }}$ century carry over feature of "liberal" democracy [to be distinguished from 'illiberal' democracy or other unrelated terms tossed about in the public square of democracy] has been the clear division between private and public property based on the natural law notion that there is a "natural realm" of property and contract that is different from the public power of the State. According to Grewal, these debates which continue today are framed around a distinction between the operational demands of public accountable power [that many say is sorely lacking] and decentralized commercial socioeconomic systems of activity in relationship to the promotion of private proper in defiance of specific

societies have little in common in terms of prosperity and inequality because their political and economic institutions differ so sharply that Uzbekistan capitalist economy has more in common with the avowedly non-capitalist economy of North Korea ; see generally, HALL, Peter and SOSKICE, David [eds.],Varieties of Capitalism: The Institutional Foundations of Comparative Advantage [Oxford: Oxford Univ.Press,2001]

56 Supra, Note 30 KANTER, James. [documenting there are calls of reform for European Parliament elections to be held in March 2019 so that candidates who run must support the democratic process and human rights values of the EU institutions the Parliament seeks to support]

57 JACOBS, Elizabeth. Everywhere and Nowhere: Politics in the Capital of the 21st Century. In BOUSHEY, Heather, DELONG, J Bradford, and STEINBAUM, Marshall [eds.] After Piketty: The Agenda for Economics and Inequality [Cambridge, MA: Harvard Univ. Press, 2017], 512-542.

58 Supra, Note 38, Grewal 
State geographic locations. ${ }^{59}$ Economic capital and its dominant global actors are possibly still attempting to operate under the old constitutional "mantras" for capitalism that supported and codified the rule of law in support of colonialism. The reference to defiance of geographic boundaries noted above is significant because the neoliberal paradigm [c. 1980-2010] supports unfettered movement of private economic capital around the globe often in disregard of the localized consequences on democracy and State domestic function. ${ }^{60}$

There is a need for a more strategic public political power to tame the current models of capitalism so a more balanced global compact can be achieved. To shift this imbalance and secure the core function of the State, new perspectives are needed for targeted research and risk taking along the domestic axis and the international axis. Such research can be designed to correct the unfettered movement of capital and the current distortions in the marketplace - both part of the planning process for a new legal constitution for capitalism. States can no longer cling to the $18^{\text {th }}$ century "invisible hand" economic theory or the moral sentiments espoused by Adam Smith. Nor can States memorize and "parrot" back $19^{\text {th }}$ century market theory based on a rationale of modern colonialism or $20^{\text {th }}$ century economic models that supported the "welfare State". Nor can a single States rely on the outdated $17^{\text {th }}$ century Westphalian notions of sovereignty by functioning as an authoritative State operating outside the $21^{\text {st }}$ century "international community of States". ${ }^{61}$ Addressing this transition at the crossroads of the rule of law and globalization may be the greatest opportunity for the European continent since World War II - to really redefine democracy and its rule of law and then design an economic paradigm to support those common rules as a new global compact.

It is not hard to see the current institutional structures of capitalism that according to Piketty exist in every society because these structures and legal systems appear to support the continuous dominance of private economic capital over the rest of a State's economy. See Diagram 02 as state economic capital dysfunction moves the social contract of democracy outside the framework of liberty. Just because the neoliberal paradigm [c 1980-2010] distorted global capitalism does not mean great human minds cannot change and redirect its powerful grip on the globe. Piketty has discussed several "laws" of capitalism as

59 Ibid, Grewal at $481 ;$ n. 51

60 Ibid.

61 Some States want to design monetary and tax policy in support of full employment of those residing in their State. Other States design domestic programs to advantage only the moneyed elite condoning corruption in government and community as a routine practice. Somewhere in between there is balance that promotes participatory democracy based on individual liberty. It has yet to be defined and operationalized. In the GeoNOMOS it is the cornerstones of the framework of liberty and the enterprise of law operating inside that framework that offers some insight into the ongoing public debate on new forms and legitimate expressions for State sovereignty. 
options in a non-juridicial sense $\mathrm{e}^{62}$ but none can really explain why the economic capital inequality has consistently remained. ${ }^{63}$

Key here is to understand the pubic square of democracy as a transformative legal system. The institutional structures of democracy depicted in the GeoNOMOS and in Piketty's arguments clearly sets up a counterbalance to a neoliberal globalization and capitalism. Piketty sets out these basic considerations concerning the negative implications of economic inequality and the function of democracy ${ }^{64}$ : First, inequality violates the basic principle of equity on voice and representation so that when citizens do not have equal voice and influence, the skewed nature of control over economic resources "poisons the promise" of equal representation. Afterall, according to Tomasi, individual economic liberty is just as important to freedom as all other liberties embraced by classical liberal thinkers and for Hurst, the corporate charter and what a Constitution chooses to protects may be two different things in terms of human relations. ${ }^{65}$

Second, if inequality means that due to neoliberal mandates for public austerity programs, a democratically elected government is less able to provide public goods, respond to a public problem, and have the capacity to promote broadly

62 Supra, Note 37 PIKETTY at 50-55, 166-170, 222, 361 [discussing his first law of capitalism and his second law of capitalism which depicts the share of national income going to capital and the ratio of savings rates to the overall growth rate; noting that when the rate of return on capital remains significantly higher than the growth rate, then the risk of divergence in wealth distribution runs very high]

63 Ibid., Piketty at $30-33 ; 361-366 ; 372-375 ; 573-575$. [Piketty's research is really a catalyst in many ways for further research on the legal, social political, and economic factors of inequality under capitalism along the GeoNOMOS vertical/domestic axis of the State and the horizontal/ international axis of the State]

64 Supra, Note 57, JACOBS, at 520-522

65 TOMASI, John. Free Market Fairness. New Jersey: Princeton University Press, [2012] [defending individual economic liberty from legal or historical perspective of political philosophy; trying to find common ground between John Rawls and Friedrich Hayek the concept of ' free market fairness' aka market democracy]; See also CORRE, Jacob I. "The Arguments and Reports of Darcy v Allen", 45 Emery L.J. 1261,1325[1996] [speaking to Darcy v Allen,11Co.Rep.84b,77 Rep.1260[K.B.1603]; pointing out that the original English Cokes' Report of an enduring nature on the questions of individual liberty arising out of the Darcy case in 1603; also noted the privileged nature of monopoly and its distortion on the common good, ultimately hurting the public square of civil society]; see also NACHBAR, Thomas B. Monopoly, Merchantilism, and the Politics of Regulation. $91 \mathrm{Va} \mathrm{L}$. R. 1313, 1324-1345, n.148 [2005]; see also SANDEFUR, Thomas The Right to Earn a Living: Economic Freedom and the Law. Washington DC, CATO Institute, [2010] 20; see also SEIGAN, Bernie H. "Protecting Economic Liberties", 6 Chap L. R.43, 50[2003] [relying on notions of substantive due process]; as general reference see JONES, Franklin D. Historical Development of the Law of Business Competition, 36 Yale L.J. 42,29[1926] ; HURST, James Willard. The Legitimacy of the Business Corporation in the Law of the United States 1790-1970 . New York: The Lawbook Exchange,2004 [noting at page 16 that what the corporate charter gave and what a Constitution protects is not just an official license but also a pattern for organizing certain human relations.] 
shared prosperity, then, there is a deeply negative impact on political processes. ${ }^{66}$ Third, excessive inequality promotes violence, high levels of vitriol and angry sentiments in the public square of democracy, that in turn, ultimately undermines the ability to define emerging legally shared democratic principles and the concept of balancing the nation State at its core. ${ }^{67}$

In order to better track certain information as the basis of global inequality, Piketty and his collaborators maintain The World Wealth and Income Database [WID] as a mechanism to begin to track the evolution of wealth and income. ${ }^{68}$ Tracking income and economic capital flow return to the top echelon [elite and military] who are part of the global elite is a potential asset that the Global Wealth Tax outlined by Piketty could also begin to help concretely identify areas of the enterprise of law where the new legal constitution for capitalism can begin. ${ }^{69}$ When using personal income taxation as a public State government tool for curbing inequality, one needs to become acutely aware of the systems role and operational function for domestic level institutions and their capacity for

66 Supra, Note 39,GREWAL at 481-483 [noting that the first constitution of capitalism was codified to support colonialism across colonies, local communities and global markets everywhere It is the legal foundation the underpins all social relations or social processes that comprise the economic system of capitalism. Yet, the focus on how legal constitutions were written to protect social processes and to secure the economic system of capitalism also incorporates key distinctions that remain important today for any newly drafted legal constitution for capital -- the key distinctions will always remain between the distinguishing definitions of "public "and "private" as well as the terms "sovereign" and "government". However, the challenge remains - a new legal constitution for capitalism will need to define these terms in light of standardized contract law principles and financial transaction centers of the marketplace in the 21st century. Although initially these historical distinctions were designed to move the market from under the rule of the monarchial type of State [including the Church], ramifications of these early legal regimes still regrettably may negatively impact how capital and theories of capitalism function in socio-political settings of today]

67 Terminology and definition of constitutional terminology as noted by Grewal sets the foundation for a new legal constitution for capitalism in this century but what of the public square of democracy at the core of the State in the GeoNOMOS and where the four cornerstones of the framework of liberty [justice, equity, individual choice and capabilities] matter in the daily function of civil society?

68 DERENONCOURT, Ellora. The Historical Origins of Global Inequality. In BOUSHEY, Heather, DELONG, J Bradford, STEINBAUM, Marshall [eds.] After Piketty: The Agenda for Economics and Inequality [Cambridge, MA: Harvard Univ. Press, 2017], at 492, 507512 [discussing Acemoglu and Robinson research "Colonial Origins"; documenting broad historical research that shows where State citizens/subjects start with little endowment, have economic and political lives proscribed by coercive and undemocratic institutions with no due process rights, subjected to coercive labor practices have a distinct lack of opportunity to accumulate wealth]; see also ACEMOGLU, Daron and ROBINSON, James. Why Nations Fail: The Origins of Power, Prosperity and Poverty [New York: Crown, 2012]; See World Wealth and Income Data Base ; available at www.wid.world

69 ZUCMAN, Gabriel. The Hidden Wealth of Nations: The Scourge of the Tax Havens [trans. Teresa Fagan] [Chicago: University of Chicago Press, 2014] 
redistribution as well as for revenue generation - these are necessary for social capital and human capital programs to mitigate inequality and address equity issues at the core of the State. ${ }^{70}$ A Global Wealth Register [GWR] as proposed by Zucman in the Hidden Wealth of Nations could be initiated and launched regionally by the $27 \mathrm{EU}$ as early as 2020 . This register would track and coordinate information gathered together regionally on owners of wealth in parts of the world where capital is primarily both private and foreign owned.

\section{Conclusions}

Piketty and others conclude that economic inequality is a profound threat to democracy, and that a new Legal Constitution for Capitalism in this century can balance the distortion created by the neoliberal paradigm for economic globalization between $1980-2010 .{ }^{71}$ Regrettably, the EU does not have a clear definition of democracy and the values of solidarity for this century. Dynamics have changed given the sheer number of nation States that have come into existence since World War II and growing politics of resentment across the Continent. Key questions remain for research on the new legal constitution for capitalism: How does the current pattern of gridlock in the EUP and EU Council privilege the status quo of elite power groups within the EU who may not be functioning within the intended purpose and collaborative principles and underlying democratic procedures for the 27EU. Are there identifiable feedback loops between political, economic and legal systems that support "place-based" segregation against States both within the 27EU and within the geographic boundaries of any given nation State? Questions remain why well intended but intermittent changes in nation State constitutional referendums, a part of popular sovereignty and the politics of resentment, have been unable to correct this inequality in economic capital including its underlying challenges to participatory democracy? ${ }^{72}$

70 Supra, Note 68, DERENONCOURT, at 491-511 [linking the way institution develop, whether they are extractive or inclusive types of institutions, and how economic institutions are key for comparative economic development]

71 Supra, Note 57, JACOBS at 527-533] [suggesting s set of future implications for varieties of capitalism on top end inequality; How does capital concentration erode the capacity of government to actually get anything done; How does an "active State" facilitate economic well-being. Are there identifiable feedback loops between political systems and economic systems that support "place-based" segregation; How does economic inequality organize the disparate distribution of public goods at the level of the nation State? Is there such a think as a politically created set of durable capital inequalities within nation States?] This author adds a few for research consideration: what role does EU political institutions play in shaping economic distribution; how does capital concentration across diverse types of capitalist regimes evidence by the 27EUt

72 In States where there are severe restrictions to suffrage and oligarchy operations in State bureaucracy is it understandable why these States have not been able to moderate differing level of economic inequality. Furthermore, as noted above, this is not an economic treatise but rather a brief legal analysis and a look at the history of capitalism understood as "laws" and why this debate continues to dominate in liberal-democratic societies into this century. 
The answer will require a very "deep dive" into EU institutional program changes, how democracy is legally defined in this century, and how States engage and legally grant competence to the EU from within their own State Constitutions. The 2020-2022 debates on the Continent will most certainly occur postBREXIT and require parallel considerations that occur simultaneously along the vertical axis [domestic operation] and horizontal axis [international operation] in the GeoNOMOS. Augmentation of constitutional rule-making for redesigning capitalism will be strategically mandated for this century as a matter of survival. The goal is to begin to identify more balanced and intentional ways of developing and utilizing economic capital, social capital and human capital at the core function of the State. In this manner, each $27 \mathrm{EU}$ member secures participatory democracy and individual liberty, promoting sustainable growth and stability with a new enterprise of law. That enterprise in turn, simultaneously secures the cornerstones of justice and equity created by the framework of liberty $\ldots$ and moves beyond the quagmire created by the politics of resentment.

\section{References}

ACCEMOGLU, Daron and ROBINSON, James Robinson, The Rise and Decline of General Laws of Capitalism, Journal of Economic Perspectives 29, 2005.

ALDER, Katya. European Elections 2019: What Were the Clear Trends? [Online] Available at: <https://www.bbc.com/news/world-europe-48420024> 27 May 2019 [Accessed 29 May 2019].

BLOCK, Pauline. Amendment to May's BREXIT Could Protect UK and EU Citizen Rights. [online] Available at: https://www.euronews.com/2019/02/21/amendment-to-may-sbrexit-deal-could-protect-uk-and-eu-citizens-rights 22 February 2019. [Accessed 10 April 2019].

BOUSHEY, Heather, DELONG, J. Bradford, and STEINBAUM, Marshall [eds], After Piketty: The Agenda for Economics and Inequality. Cambridge, MA: Harvard University Press, 2017.

BREXIT Global Recession. [Online\} Available at <https://www.independent.co.uk/ voices/brexit-global-recession-germany-stock-markets-crash-record-closinghighs-a8793401.html> [Accessed 25 May 2019].

BROWNE, John. UK's Minister Commits to Successful Brexit, Townhall Finance [online]. Available at <https://finance.townhall,con/columnists/johnbrowne/2016/08/05/uksprime-minister-commits-tosuccessful-brexit-n2201876>. 5 August 2016 [Accessed 31 March 2019].

COHEN, Roger. Britain's BREXIT Leap in the Dark. [online] Available at: <https://www. nytimes.com/2016/06/25/opinion/britains-brexit-leap-in-the-dark.html> 24 June 2016. [accessed 31 March 2019].

CORRE, Jacob I. The Arguments and Reports of Darcy v Allen. 45 Emery L.J. 1261. 1996

DAVIS, M and MONK, D.B. [eds]. Evil Paradises: Dreamworlds of Neoliberalism. New York: New Press, 2007.

ERLANDER, Steven. Brexit' Opens Uncertain Chapter in Britain's Storied History. [Online] Available at:<https:www.ntyimes.com/2016/06/25/world/Europe/Brexit_europeanunion-uncertain-charpter-in-britains-storied-history.html> 24 June 2016 [Accessed 31 March 2019]. 
European Elections: Country - by - Country Roundup. [Online] Available at: <https:// www.bbc.com/news/world-europe-48420697> 27 May 2019 [Accessed 27 May 2019].

European Elections: Power Blocs Lose Grip on Parliament.[online] Available at: <https:// www.bbc.com/news/world-europe-48417744> 29 May 2019 [Accessed 29 May 2019].

GREWAL, David. The Legal Constitution of Capital. In BOUSHEY, Heather, DELONG, J. Bradford, and STEINBAUM, Marshall [eds], After Piketty: The Agenda for Economics and Inequality. Cambridge, MA: Harvard University Press, 2017.

HALL, Peter and SOSKICE, David [eds.], Varieties of Capitalism : The Institutional Foundations of Comparative Advantage [Oxford: Oxford Univ.Press, 2001.

HAMULÁK, Ondrej. National Sovereignty in the European Union - View from the Czech Perspective. Cham, Springer International, 2016.

HARVEY, D. The Enigma of Capital: And the Crisis of Capitalism. London: Profile Books, 2011.

Here's What Many Journalists Missed in When Covering The Brexit Vote. [online]Available at:<https://www.washingtonpost.com/news/monkey-cage/wp/2016/08/04/ heres-what-many-journalists-missed-when-covering-the-brexit-vote/ 4 August 2016 [Accessed 27 May 2019].

HONT, I., KAPOSSY, B. and SONENSCHER M. Politics in Commercial Society [Cambridge, MA: Harvard University Press, 2015.

HURST, James Willard. The Legitimacy of the Business Corporation in the Law of the United States 1790-1970. New York: The Lawbook Exchange, 2004.

JONES, Franklin D. Historical Development of the Law of Business Competition, 36 Yale L.J. 42, 1926.

KANTER, James. Far Right Leaders Hate EU Institutions But Like Their Paychecks. [online]. Available at <https://www.nytimes.com/2017/04/27/world/europe/> 27 April 2017 [Accessed 31 March 2019].

KIRKA, Danica. UK Central Bank Tried to Soften BREXIT Shock in Economy, ABC News/ Associated Press [online]. Available at https://abcnews.go.cpm/International/wiresStory/uk-central-bank-economy-brexit-stimulus-41112988 [Accessed 10 January 2019].

KONCEWICZ,Tomasz. Understanding the Politics of Resentment. [online] Verfblog, 2017/9/28. Available at <https://verfassungblog.de/understanding-the-politics-ofresentment/> 28 September 2017. [Accessed 22 March 2019].

KRUGMAN, Paul Krugman, Trade and Wages Reconsidered. Washington, D.C.: Brookings Institute: Papers on Economics,2008.

KRUGMAN, Paul. Why We're in a New Guilded Age. In BOUSHEY, Heather, DELONG, J. Bradford, and STEINBAUM, Marshall [eds], After Piketty: The Agenda for Economics and Inequality. Cambridge, MA: Harvard University Press, 2017.].

McMICHAELS, P., Development and Social Change: A Global Perspective. New York: Sage Pubs, 2008.

MILGATE, M., STIMPSON, S.C. After Adam Smith: A Century of Transformation in Politics and Political Ideology. New Jersey: Princeton University Press, 2009

NACHBAR, Thomas B. Monopoly, Merchantilism, and the Politics of Regulation. $91 \mathrm{Va}$ L. R. 1313, 2005.

NIB, J. EUs Juncker Hails Macron.[online]. Available at https://jonnib.wordpress. com/2017/09/26/eus-juncker-hails-macron-speech-as-very-european. 26 September 2017 [Accessed 22 March 2019].

No Deal Brexit Like Jumping Off Cliff Without Parachute Says Former WTO Leader. 
[Online] Available at: <https://www.euronews.com/2019/02/22/no-deal-brexit-likejumping-off-cliff-without-parachute-says-former-wto-leader $>22$ February 2019. [Accessed 10 May 2019].

NOLAN,P., Capitalism and Freedom : The Contradictory Character of Globalization. New York: Anthem Press, 2008.

O'ROURKE, K.A.C. Sovereignty Post-Brexit, The State's Core Function and EU Reintegration. European Studies: The Review of European Law, Economics and Politics, CAES, 2017, Vol 4 [Wolter-Kluwer, March 2018], 140-164.

OSTRY, Jonathan, LOUNGANI, Prakash, and FUCERI, David, Neoliberalism Oversold, Finance \& Development, June 2016, Vol 53, No 2[Online] Available at $<$ https://www. imf.org/external/pubs/ft/fandd/2016/06/ostry.htm> June 2016 [Accessed 10 April 2019].

OXFAM, Working for the Few: Political Capture and Economic Inequality. Oxford: Oxfam International, 2014.

PECH Laurent, SCHEPPELE, Kim Lane. Poland and the European Commission, Part III: Requiem for the Rule of Law, VerfBlog,2017/10/03, [online] Available at: <https://verfassungblog.de/poland-and-the-european-commission-part-iii-requieum-for-therule-of-law $>03$ October 2017[Accessed 10 January 2019].

PICKETTY, Thomas. Capital in the Twenty-First Century, trans Arthur Goldhammer. Cambridge, MA: Belknap Press of Harvard University,2014

RAMIREZ, S.A. Taking Economic Rights Seriously After the Debt Crisis. 42 Loy. U. Chi. L. J. 713, 2014.

REICH, Robert. Saving Capitalism : For The Many, Not The Few. New York: Knopf, 2015.

RODRIK, DANI, The Fatal Flaw of Neo-liberalism [Online]. Available at <https://www. theguardian.com/news/2017/nov/14/the-fatal-flaw-of-neoliberalism-its-bad-economics $>$. 14 November 2017] [Accessed 10 January 2019].

RODRIK, Dani, The Globalization Paradox: Democracy and the Future of the World Economy. New York: W.W. Norton \& Co., 2011.

ROTHSCHILD, E. Adam Smith and Conservative Economics. Economic History Review $45,1992$.

SANDEFUR, Thomas The Right to Earn a Living: Economic Freedom and the Law. Washington DC, CATO Institute, 2010.

SANFORD, Alasdair. Both Brexit and Remain MPs Opposed May's Deal and Why [online]. Available at: <https://www.euronews.com/2018/12/07/what-is-in-theresa-may-sbrexit-deal-and-why-is-it-so-unpopular $>12$ July 2018 [Accessed 10 January 2019]

SANFORD, Alasdair. No Deal BREXIT : What Would 'WTO' Mean for UK-EU trade? [online] Available at: <https://www.euronews.com/2018/12/19/how-would-uk-eutrade-be-affected-by-a-no-deal-brexit $>22$ February 2019 [Accessed 16 May 2019]

SEIGAN, Bernie H. Protecting Economic Liberties. 6 Chap L. R.43, 2003

SMITH, Adam. An Inquiry Into the Nature and Causes of the Wealth of Nations 1.1, London: Publisher William Strahan, 1776 ; see also tandem text, SMITH, Adam. The Theory of Moral Sentiments. Scotland, 1759.

SOSKICE, D. Capital in the Twenty First Century: A Critique. British Journal of Sociology, Vol 65, No.4, 2014.

STIGLITZ, J. Free Markets and the Sinking of the Global Economy. London: Allen Lane,2010 TIROLE, Jean. Economics for The Common Good. New Jersey: Princeton University Press, 2017.

TOMASI, John. Free Market Fairness. New Jersey: Princeton University Press, 2012. 
UITZ, Renata. The Return of the Sovereign: A Look at the Rule of Law in Hungary-and In Europe. VerfBlog,2017/4/05.[Online] Available at: <https://verfassungsblog.de/thereturn-of-siveireignty-a-look-at-the-rule-of-law-in-hungary-and-in-eruope $>4$ May 2017 [Accessed 16 May 2019].

What Would A No Deal Brexit Mean for Citizen Rights. [online] Available at: <https:// www.euronews.com/2019/01/10/what-would-a-no-deal-brexit-mean-for-citizensrights $>22$ February 2019. [Accessed 27 May 2019].

WOOD, A. The Free Development of Each [Oxford: Oxford University Press, 2014.

World Wealth and Income Data Base.[WID] [Online]. Available at www.wid.world

ZUCMAN, G. The Hidden Wealth of Nations. Chicago: University of Chicago Press, 2015. 
ICLR, 2019, Vol. 19, No. 1.

The GeoNOMOS Model:

The Core and Enterprise of State Functions

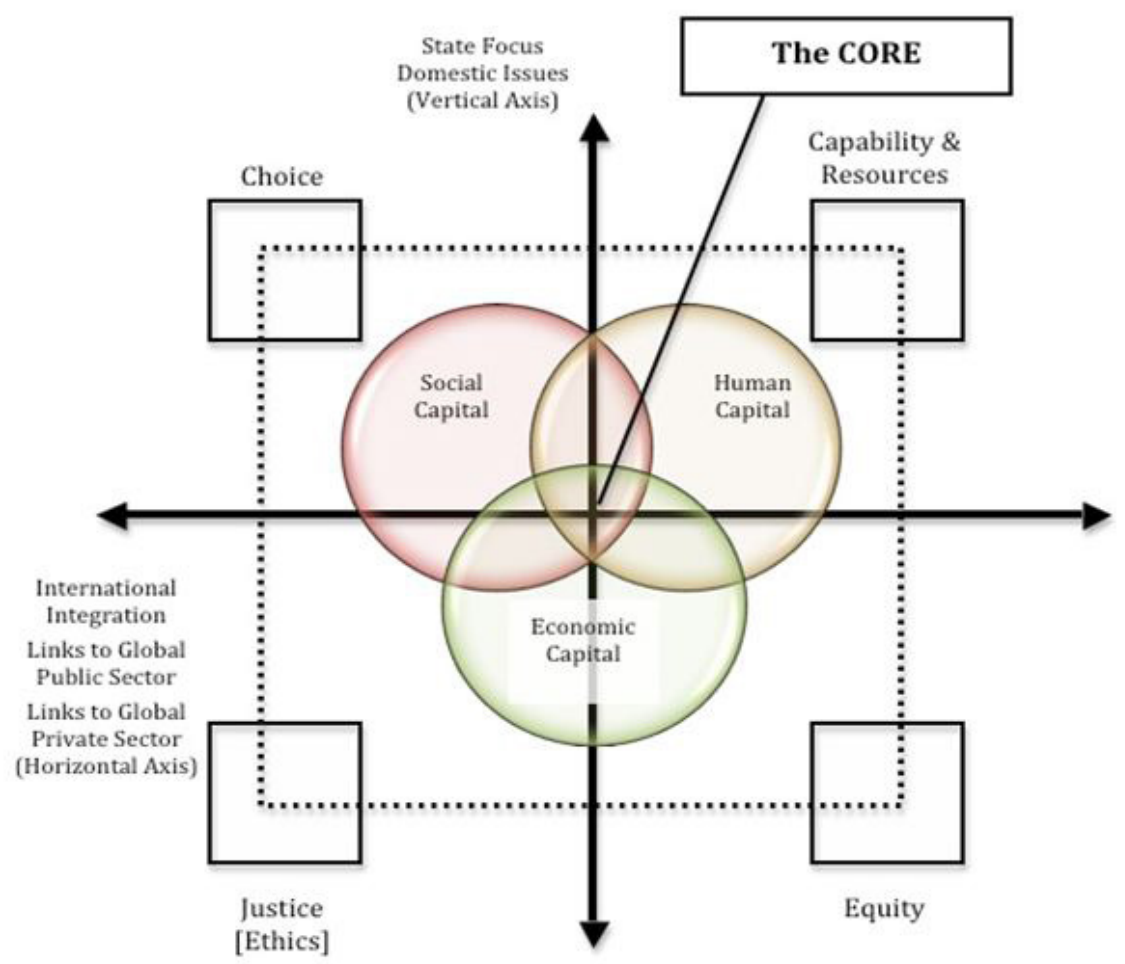

DIAGRAM 06

C C KAREN A. O'ROURKE

MAY 2010

Published by Palacký University Olomouc, Czech Republic, 2019.

ISSN (print): 1213-8770; ISSN (online): 2464-6601 
ICLR, 2019, Vol. 19, No. 1.

The GeoNOMOS Model:

The Shifting of Economic Capital -Extreme Condition A/The Loss of State Core

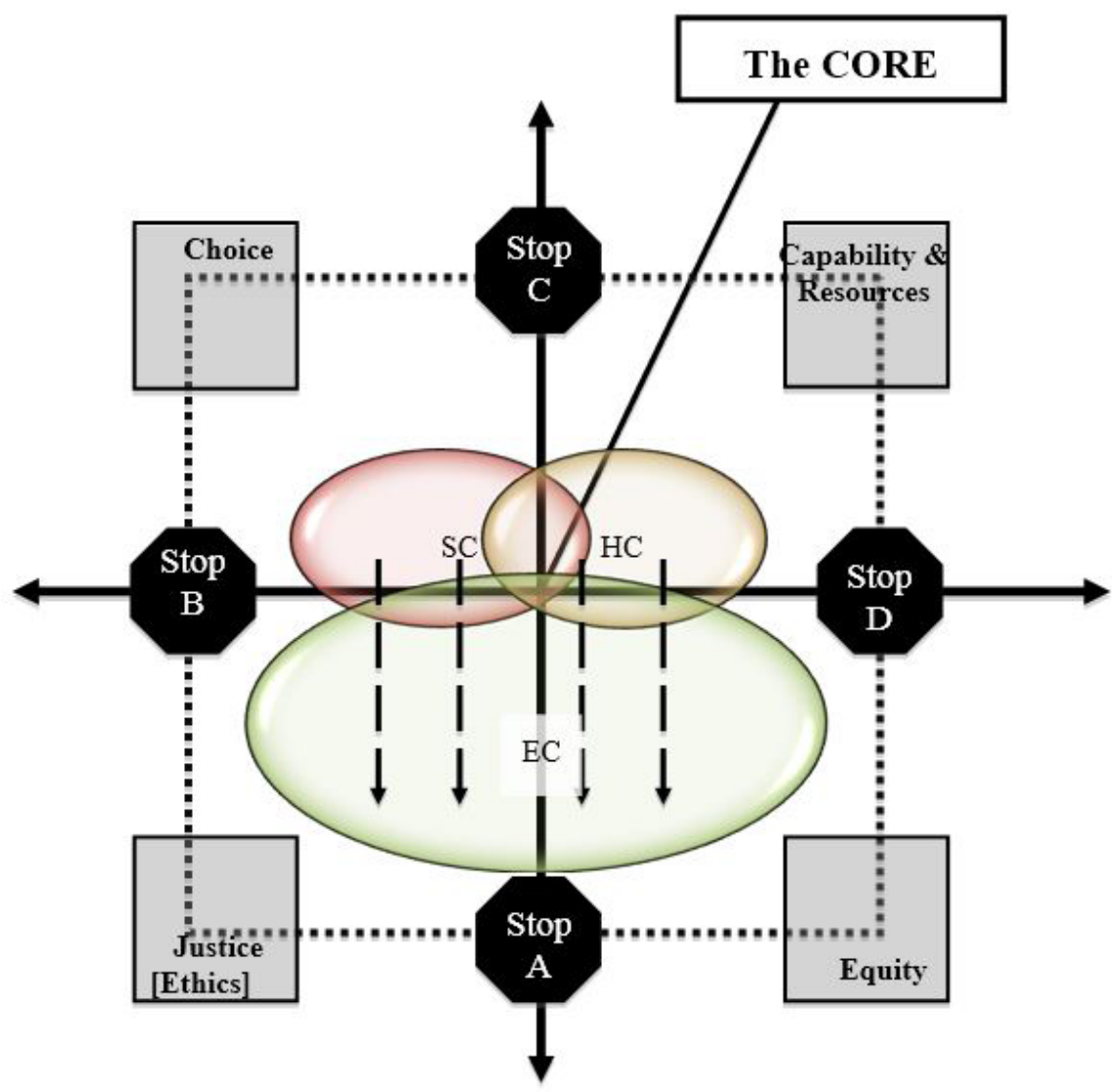

DIAGRAM 08

(c) KAREN A.

O'ROURKE 